\title{
Temporal variability of climate at the US Long-Term Ecological Research (LTER) sites
}

\author{
David Greenland $^{1, *}$, Timothy G. F. Kittel ${ }^{2,3}$ \\ ${ }^{1}$ Department of Geography, University of North Carolina, Chapel Hill, North Carolina 27599-3220, USA \\ ${ }^{2}$ National Center for Atmospheric Research, Box 3000, Boulder, Colorado 80307-3000, USA \\ ${ }^{3}$ Natural Resource Ecology Laboratory, Colorado State University, Ft. Collins, Colorado 80523, USA
}

\begin{abstract}
We examine the temporal climate variability of 18 Long-Term Ecological Research (LTER) sites in the United States including Puerto Rico and Antarctica. Annual and seasonal means of air temperature and totals of precipitation were collected from sites for the period 1957-1990 and, for some sites, for longer periods ranging up to a century. Fourteen of the sites show a positive trend in annual mean temperature during the 1957-1990 period, while 4 show a negative trend. Statistical evidence exists at some groups of sites for a step function in temperature and precipitation occurring in the $14 \mathrm{yr}$ either side of 1976. Comparisons suggest that with respect to changes in time, the climates of sites in the North Central part of the US tend to act in concert as one group while the climates of sites near the East Coast tend to act together as a separate group. The climates of the Antarctic sites also seem to act in a coherent manner. There is less coherence among the climates of other LTER sites. These patterns are shown in the variations of the detrended standardized $5 \mathrm{yr}$ moving averages of temperature and precipitation at the sites. The patterns are associated with variations in the values of teleconnective indices, particularly the North Atlantic Oscillation index for the North Central and East Coast LTER sites and the Pacific North American index for the Alaskan and Pacific Northwest group of LTER sites. The climates of some sites, such as those in the center of the country, show some evidence of 'cyclicity' but the record length is too short to make definitive statements about this. We review the variability of some ecological effects that have been documented at LTER sites as this variability relates to the described climate.
\end{abstract}

KEY WORDS: Climate variability $\cdot$ Climatic trends $\cdot$ LTER $\cdot$ United States $\cdot$ Puerto Rico $\cdot$ Antarctica

\section{INTRODUCTION}

The US Long-Term Ecological Research (LTER) program is by its very nature intimately concerned with climate variability as one of the major driving forces of ecosystem function related to long-term ecological variability (Callahan 1984, Van Cleve \& Martin 1991). Interest in the sensitivity of ecosystem, population, and community dynamics to climate variability is also driven by questions related to understanding the potential ecological consequences of global climate change (Bolin et al. 1986, IGBP 1990, Melillo et al. 1990, 1996). Recognizing such factors, we provide here a systematic

*E-mail: greenlan@email.unc.edu examination of the climate variability of LTER sites applying the same methodology to all sites. This study is limited to the interannual and decadal scale. Even though we recognize the importance of a broad set of climate variables for understanding climatic effects on ecological processes, we limit this investigation to seasonal and annual values of 4 variables: mean, maximum, and minimum air temperatures, and total precipitation.

The LTER sites (Table 1, Fig. 1, Callahan 1984) were chosen primarily on the basis of the quality of research proposed and not to give an effective geographical coverage of the country. As a result, it is not the goal of this analysis to give a representative picture of climate change and variability across the country. Rather, our 
Table 1. LTER sites in 1996

\begin{tabular}{|c|c|c|c|}
\hline Site & Abbreviation & Ecosystem & Climate \\
\hline $\begin{array}{l}\text { H. J. Andrews Exp. Forest } \\
\text { (Oregon) }\end{array}$ & AND & Coniferous forest & Marine west coast \\
\hline $\begin{array}{l}\text { Arctic Tundra } \\
\text { (Alaska) }\end{array}$ & ARC & Arctic tundra & Arctic tundra \\
\hline $\begin{array}{l}\text { Bonanza Creek Exp. Forest } \\
\text { (Alaska) }\end{array}$ & BNZ & Boreal forest & Subarctic \\
\hline $\begin{array}{l}\text { Cedar Creek Nat. History Area } \\
\text { (Minnesota) }\end{array}$ & CDR & Hardwood forest/ tallgrass prairie & Humid continental \\
\hline $\begin{array}{l}\text { Coweeta Hydrol. Lab. } \\
\text { (N. Carolina) }\end{array}$ & CWT & Deciduous forest & Humid continental \\
\hline $\begin{array}{l}\text { Hubbard Brook Exp. Forest } \\
\text { (New Hampshire) }\end{array}$ & HBR & Northern hardwood & Humid continental \\
\hline $\begin{array}{l}\text { Harvard Forest } \\
\text { (Massachusetts) }\end{array}$ & HFR & Hardwood/whitepine/ hemlock transition & Humid continental \\
\hline $\begin{array}{l}\text { Jornada } \\
\text { (New Mexico) }\end{array}$ & JRN & Desert & Sub tropical desert \\
\hline $\begin{array}{l}\text { Kellogg Biological Station } \\
\text { (Michigan) }\end{array}$ & KBS & Agricultural & Humid continental \\
\hline $\begin{array}{l}\text { Luquillo Exp. Forest } \\
\text { (Puerto Rico) }\end{array}$ & LUQ & Tropical rainforest & Tropical rainforest \\
\hline $\begin{array}{l}\text { Konza Prairie } \\
\text { (Kansas) }\end{array}$ & KNZ & Tallgrass prairie & Mid-latitude steppe \\
\hline $\begin{array}{l}\text { McMurdo Dry Valleys } \\
\text { (Antarctica) }\end{array}$ & $\mathrm{MCM}$ & Cold desert aquatic and terrestrial & Polar \\
\hline $\begin{array}{l}\text { North Temperate Lakes } \\
\text { (Wisconsin) }\end{array}$ & NTL & $\mathrm{N}$ temperate lake mixed forest & Humid continental \\
\hline $\begin{array}{l}\text { Niwot Ridge/ Green Lakes Valley } \\
\text { (Colorado) }\end{array}$ & NWT & Alpine tundra & Highland \\
\hline $\begin{array}{l}\text { Palmer Station } \\
\text { (Antarctica) }\end{array}$ & PAL & Pelagic marine & Polar tundra \\
\hline $\begin{array}{l}\text { Sevilleta } \\
\text { (New Mexico) }\end{array}$ & SEV & Desert/grassland/forest transition & Low-latitude desert \\
\hline $\begin{array}{l}\text { Shortgrass Steppe formerly Central } \\
\text { Plains Exp. Range (Colorado) }\end{array}$ & SGS/CPR & High plains grassland & Mid-latitude steppe \\
\hline $\begin{array}{l}\text { Virginia Coast Reserve } \\
\text { (Virginia) }\end{array}$ & VCR & Barrier island & Humid subtropical \\
\hline
\end{tabular}

overall goal is to provide a characterization of climate variability at LTER sites in terms of synoptic-scale factors producing variability within and between years. Within this framework our sub-goals are firstly to identify the major changes and types of changes which have taken place at the LTER sites; secondly to place the climate variability at LTER sites in the context of what is already known at the national and global level; thirdly to group LTER sites into categories of somewhat similar behavior as far as climate variability is concerned; and fourthly to point out linkages between the climate variability and the ecosystem response.

The structure of this paper is designed to meet these goals. First, we discuss the collection and processing of the data. We present a data set with data for a common set of years-1957-1990. We investigate trends and the possibility of step function changes in the data. Then we look at the temporal variability of temperature and precipitation at groups of LTER sites. The groups are based mainly on geographical regions. We also compare this variability with variability in some pertinent teleconnective indices for the same period. Finally, we point out some ecological implications of the findings of temporal climatic variability found at LTER sites.

\section{DATA COLLECTION AND PROCESSING}

We collected a set of monthly temperature and precipitation data that is comparable across LTER sites. The steps used to build the time series data set were 


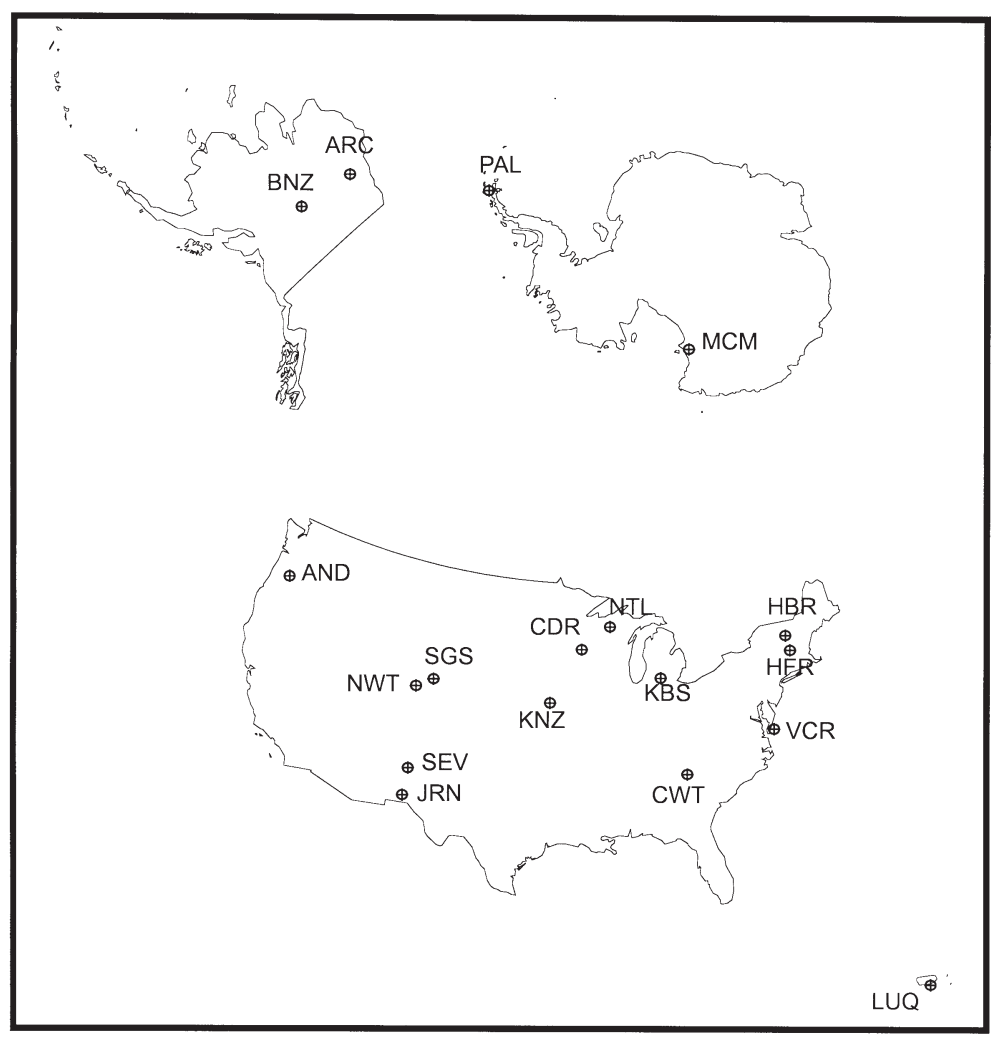

Fig. 1. LTER sites in 1996

first to download available data from the World Wide Web sites of the LTER sites. Then site data managers were asked to select a representative station if the LTER site had data from more than 1 observing location posted on its Web page. If extra data were needed, attempts were first made to obtain these from the LTER site data managers. If this was unsuccessful for any reason, we identified the nearest appropriate National Weather Service (NWS) station which had a long record. There were often no United States Historical Climate Network (USHCN, Karl et al. 1990) stations close enough to the LTER sites to be useful. Thus, in some cases, non-USHCN NWS stations were selected. LTER site personnel were first asked to make suggestions for the selection of an alternate proxy site. If no suggestion was forthcoming from this source then the state climatologist of the state containing the LTER site was contacted for help and provision of data for the station identified. Regression equations were then constructed to relate the LTER site data with data from the proxy sites and long period data sets were constructed in this manner. Details of this procedure for each site may be found on the LTER climate description Web site http://lternet.edu/documents/Publications/ climdes/climdes1.html and the alternate climate stations used are summarized in Table 2.
We believe that in most cases the above procedure resulted in a time series accurate enough for intersite comparison. Yet we recognize that the process does lead to the establishment of sets of data of differing degrees of accuracy. This problem is minimized by the various data aggregation, standardization, and manipulation processes performed. Within this context 3 sites emerge whose results should be treated with caution. These sites are the Arctic Tundra; eastern Brooks Range, Alaska (ARC), Luquillo Experimental Forest, Puerto Rico (LUQ), and McMurdo Dry Valleys, Antarctica (MCM). Precipitation data for MCM are not analyzed here because of doubts about the data reliability. In the case of ARC, the nearest proxy station, Barrow, was approximately $400 \mathrm{~km}$ NNW away and in a rather different, maritime-influenced climate. Because the LUQ site El Verde station only has data from 1975, long-term proxy data for LUQ were obtained from low elevation stations which tend to be warmer and drier than LUQ itself. The MCM LTER site in the Dry Valleys is rather different from the coastal base of McMurdo Station, which was used as a proxy station. In addition, only data for mean temperature were available from the British Antarctic Survey site at Faraday as the proxy station for the other Antarctic LTER site Palmer Station (PAL) and then only for the years 1957-1989.

Table 2. List of LTER sites and the NWS proxy stations used to obtain a long data record

\begin{tabular}{|ll|}
\hline LTER site & NWS proxy station \\
\hline AND & Leaburg, Cottage Grove, Corvallis, OR \\
ARC & Barrow, AK \\
BNZ & Fairbanks, AK \\
CDR & Cambridge, MN \\
CWT & \\
HBR & Woodstock, NH \\
HFR & Amherst, MA \\
JRN & \\
KBS & Gull Lake, MI \\
KNZ & Manhattan, KS \\
LUQ & Fajardo, Paraiso, PR \\
MCM & McMurdo Station \\
NTL & Minocqua, WI \\
NWT & \\
PAL & Faraday Station \\
SEV & Socorro, NM \\
SGS & ARS site Pawnee, CO \\
VCR & Painter, VA \\
\hline
\end{tabular}


Some LTER sites are representative of more than 1 biome. In these cases proxy climatic data, where necessary, are taken from a location most often used by the personnel of that site. The use of Soccorro, NM, for the Sevilleta sites is an example of this. Data for ARC, LUQ, MCM, and SEV are included in parts of the following analyses. We believe the possible uncertainty of the data is not large enough to alter any of the general conclusions that are drawn.

Once actual or proxy monthly mean temperature and monthly total precipitation data were assembled for an LTER site, they were aggregated into seasonal and annual average or total data. The annual value in Tables 3 to 6 represents the value calculated from the average or total of the monthly values. The seasons for all Northern Hemisphere LTER sites were taken as follows: December (of the previous year), January, and February for winter; March, April, and May for spring; June, July, and August for summer; and September, October and November for fall. In addition, these groups of months were taken respectively for summer, fall, winter, and spring for Antarctic sites. The results in Tables 3 to 6 allow for the fact that the seasons fall in different months in the northern and southern hemispheres. So, for example in Table 3 summer values for MCM and PAL refer to the average of the months of December, January, and February. Winter water year totals of precipitation were also computed as the precipitation total from October to April for Northern Hemisphere stations with the winter water year being named for the calendar year which included the January to April months. Winter water year was defined as April to October for Antarctic sites. Annual mean temperature and total precipitation were also calculated. Missing data points in the proxy data sets and site data sets were treated using the method of first differences described by Linacre (1992, p. 62). The method assumes a more-or-less constant difference between temperatures or constant ratio between precipitation values between the values at the proxy station and those at the station of interest. Missing data points in proxy station time series were filled in with the long-term average for the missing point estimated over the longest available data set.

Data on the teleconnective indices (TI) were collected from several sources. The North Pacific (NP) Index is the area-weighted sea level pressure (SLP) over the region $30-65^{\circ} \mathrm{N}, 160^{\circ} \mathrm{E}-140^{\circ} \mathrm{W}$ (Trenberth \& Hurrell 1994). The North Atlantic Oscillation (NAO) is a measure of the SLP difference over the North Atlantic Ocean between the Icelandic Low and Azores High-Pressure areas. Standardized monthly values of the NAO index are computed from the SLP difference between Delgada, Azores, and Stykkisholmur, Iceland (Van Loon \& Rogers 1978). We obtained monthly mean values of the NP from the data set for the period Janu- ary 1899-March 1998 provided by Drs Kevin Trenberth and James Hurrell on the Web site of the National Center for Atmospheric Research at Boulder, Colorado. We filled in 1 missing monthly value by using the average of the values of the months on either side of the missing data point. We obtained values of the NAO courtesy of Dr Jeffrey Rogers from the Ohio State University and used the same method for filling 1 missing data point. We standardized the monthly data, averaged for winter, of the NP and NAO data sets for the period 1900-1998. The Southern Oscillation Index (SOI) is the standardized SLP difference between Tahiti and Darwin, Australia. SOI data were obtained from the Climate Prediction Center (CPC) of the NWS at http://www.cpc.ncep.noaa.gov/data/cddb/. The Pacific North American (PNA) index measures the zonal/meridional flow of air across North America. PNA data were obtained from the Center for Environmental Prediction (CEP) at http://www.cpc.ncep.noaa. gov/data/teledoc/telecontents.html. A value of zero was given to this index during the summer months, when the first principal component does not appear as a leading mode in explaining the SLP pattern.

The LTER climate data set consisted of values of monthly mean maximum, minimum and mean temperature and monthly total precipitation for the years 1957-1990 for which we had data for the LTER sites existing in 1996. This was called the Common Data Period (CDP). Three newer LTER sites, at Baltimore, Phoenix, and Plum Island Ecosystem located on the northern Massachusetts coast, and 2 new marine and 1 freshwater aquatic sites were established after this analysis was performed and are not considered here. Standardized anomaly values were produced by subtracting the series mean from the observation and dividing by the series standard deviation (Wilks 1995). TI data were either standardized the same way (NAO) or were already standardized at the data source (NP, PNA, SOI). We did not detrend the TI data because in some cases the original raw data were not available.

An understanding of the climate variability at the LTER sites in terms of the moving averages may be obtained by examining how the values at groups of sites vary. Consequently the sites were divided into groups based on the results of earlier principal component analysis and geographical and physical considerations. The groups used were called North Central (CDR, NTL, KBS, KNZ), East Coast (CWT, VCR, HBR, HFR), Central Grasslands and South West (KNZ, SGS, JRN, SEV) and Alaska and Pacific North West (PNW, AND, ARC, BNZ). This grouping omits NWT, LUQ, and the Antarctic Stations (MCM and PAL), which for different reasons do not fit into the other groups and are placed here in a remaining group. In some parts of the analysis, KNZ was included in both the North Cen- 
tral and Central Grassland and South West groups, and NWT was included in the Central Grasslands and South West Group in order to aid in comparison.

\section{ANALYSIS}

\subsection{Trends: common period 1957-1990}

We first discuss linear trends found for the common period (1957-1990) (Tables 3 to 6). Significance values in Tables 3 to 5 relate to the significance of the linear regression line from which the slope/trend is computed. Annual mean temperature values at almost all sites have slightly increasing values for the period (Table 3, Fig. 2). The largest of these increases is $0.098^{\circ} \mathrm{C} \mathrm{yr}^{-1}(\mathrm{p}<0.001)$ for SGS, which is almost $1^{\circ} \mathrm{C}$ for a $10 \mathrm{yr}$ period, with the trends statistically significant in all seasons except winter. Most other positive rates are much smaller than this, the median (including negative values) being $0.017^{\circ} \mathrm{C} \mathrm{yr}^{-1}$ or about $0.5^{\circ} \mathrm{C}$ over the last 3 decades. The Antarctic sites have some large seasonal rates of change, with $\mathrm{MCM}$ recording $\left.+0.336^{\circ}{\mathrm{C} \mathrm{yr}^{-1}}^{-1} \mathrm{p}<0.01\right)$ for spring. PAL also records a

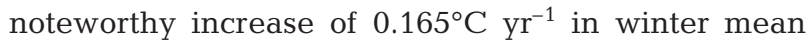
temperatures. Earlier studies have confirmed rapidly increasing temperatures in the Antarctic Peninsular and their possible relation to the retreat of ice shelves and the calving of icebergs (King 1994, Stark 1994, Vaughan \& Lachian-Cope 1995). Significant increases are also seen in annual values at BNZ, CWT, HFR and VCR. The maximum decreases in annual mean temperature trends are found at NTL and NWT but these are not statistically significant.

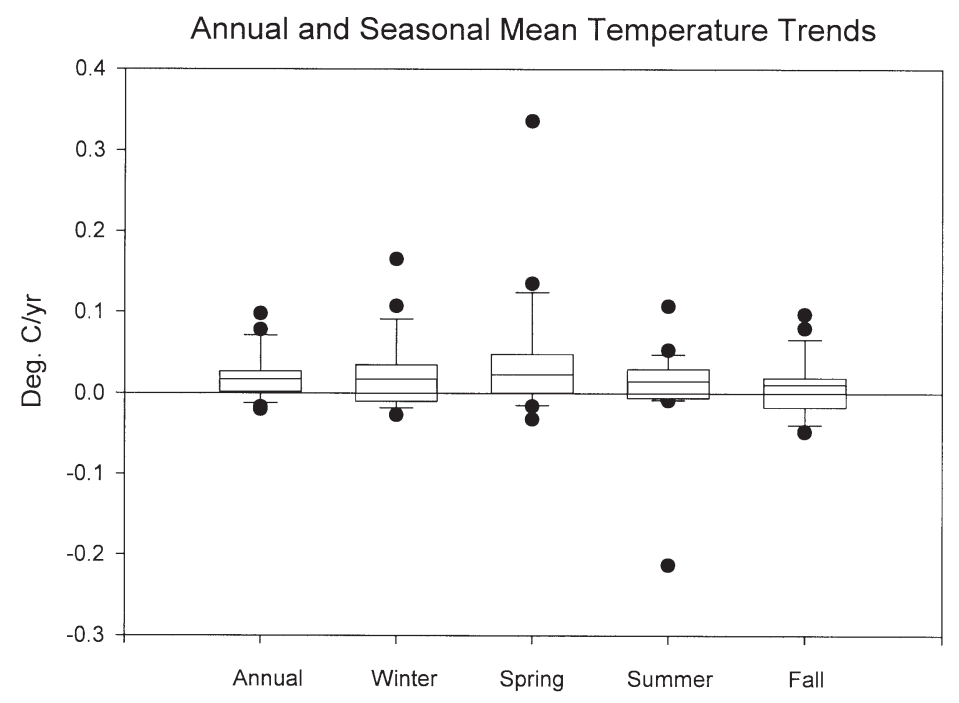

Fig. 2. Box plot of annual and seasonal mean temperature trends
Table 3. Linear trends $\left({ }^{\circ} \mathrm{C} \mathrm{yr}^{-1}\right)$ in mean temperature for annual and seasonal values over the period 1957-1990. Significance: ${ }^{*} p<0.05,{ }^{* *} p<0.01,{ }^{* * *} p<0.001$. The seasons for all Northern Hemisphere LTER sites were taken as December (of the previous year), January, and February for winter; March, April, and May for spring; June, July, and August for summer; and September, October and November for fall; these groups of months were taken respectively as summer, fall, winter, and spring for Antarctic sites

\begin{tabular}{|lcrccc|}
\hline Site & Annual & Winter & Spring & Summer & Fall \\
\hline AND & 0.003 & -0.018 & 0.026 & -0.007 & 0.016 \\
ARC & 0.022 & 0.035 & -0.032 & 0.053 & 0.034 \\
BNZ & $0.056^{* *}$ & 0.107 & $0.099^{*}$ & $0.034^{*}$ & 0.003 \\
CDR & 0.018 & 0.021 & 0.048 & 0.020 & -0.021 \\
SGS & $0.098^{* * *}$ & 0.055 & $0.135^{* * *}$ & $0.107^{* * *}$ & $0.097^{* * *}$ \\
CWT & $0.022^{*}$ & 0.014 & 0.020 & $0.022^{*}$ & 0.019 \\
HBR & 0.013 & 0.031 & 0.021 & -0.007 & -0.003 \\
HFR & $0.035^{* *}$ & 0.047 & $0.039^{*}$ & $0.030^{* *}$ & 0.013 \\
JRN & 0.002 & -0.001 & -0.009 & 0.005 & 0.009 \\
KBS & -0.001 & -0.014 & -0.016 & 0.010 & 0.011 \\
KNZ & 0.021 & 0.023 & 0.034 & 0.026 & 0.012 \\
LUQ & -0.001 & -0.010 & -0.012 & 0.007 & 0.011 \\
MCM & 0.017 & -0.008 & $0.336^{* * *}$ & $-0.213^{* * *}-0.017$ \\
NTL & -0.017 & -0.018 & 0.002 & -0.009 & $-0.047^{*}$ \\
NWT & -0.020 & -0.027 & 0.001 & -0.006 & -0.048 \\
PAL & 0.078 & 0.165 & 0.033 & 0.035 & 0.080 \\
SEV & 0.007 & -0.002 & $0.051^{* *}$ & 0.004 & -0.020 \\
VCR & $0.027^{* *}$ & 0.025 & 0.015 & $0.029^{*}$ & 0.027 \\
aPeriod is $1957-1987$ & & & \\
\hline
\end{tabular}

Some studies (e.g. Nicholls et al. 1996) have suggested recent warming has been seen more in minimum temperatures than in maximum temperatures. Maximum and minimum temperatures were examined to see if this suggestion is supported by temperature trends at LTER sites. Maximum temperatures (Table 4) showed the largest increasing trend in annual values of $0.079^{\circ} \mathrm{C} \mathrm{yr}^{-1}$ (SGS) $(\mathrm{p}<0.001)$ and the

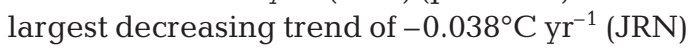

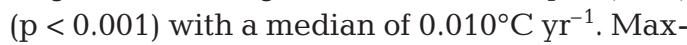
imum and minimum temperatures for $\mathrm{MCM}$ and PAL are not available. The comparable statistics for minimum temperatures (Table 4) show the maximum increase rate for annual mean minima to be $0.116^{\circ}{\mathrm{C} \mathrm{yr}^{-1}}^{-1}$ (SGS) $(\mathrm{p}<$ 0.001 ), the largest decreasing trend being $-0.025^{\circ} \mathrm{C} \mathrm{yr}^{-1}$ at NWT with a median of $0.019^{\circ}{\mathrm{C} \mathrm{yr}^{-1}}$. Sixty-five percent of the seasonal values from all sites show a more positive trend value for minimum temperatures compared to maximum temperatures. In the 19 cases of paired maximum and minimum temperature trends for a season and site where the trend in one of the pairs of values is statistically significant, there are 12 cases where the trend for the minimum temperature exceeds that for the maximum temperature compared to 7 
where the reverse is true. In the cases of the largest increasing trend and median values of all trends, trends for minima temperature values also are more positive than those for maxima temperature values. Thus temperature values at LTER sites do provide evidence to support the findings of studies that used many more observation sites to suggest a greater increase in minima compared to maxima temperatures. However the LTER evidence is not uniform across sites and seasons. By far the greater number of statistically significant trends of warming at LTER sites occur in the spring and summer seasons. Increased warming during these seasons will have a potentially positive effect on plant growth and development, though this will be

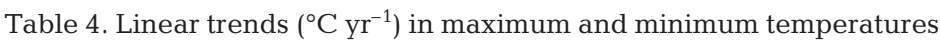
for annual and seasonal values over the period 1957-1990. Significance: ${ }^{*} \mathrm{p}<0.05,{ }^{* *} \mathrm{p}<0.01,{ }^{* * *} \mathrm{p}<0.001 . T_{\max }, T_{\min }$ data are not available for PAL

\begin{tabular}{|c|c|c|c|c|c|c|}
\hline Site & & Annual & Winter & Spring & Summer & Fall \\
\hline AND & $\begin{array}{l}T_{\max } \\
T_{\min }\end{array}$ & $\begin{array}{l}0.007 \\
0.005\end{array}$ & $\begin{array}{r}-0.001 \\
0.003\end{array}$ & $\begin{array}{l}0.037 \\
0.009\end{array}$ & $\begin{array}{r}-0.019 \\
0.008\end{array}$ & $\begin{array}{l}0.015 \\
0.008\end{array}$ \\
\hline ARC & $\begin{array}{l}T_{\max } \\
T_{\min }\end{array}$ & $\begin{array}{l}0.026 \\
0.018\end{array}$ & $\begin{array}{l}0.055 \\
0.052\end{array}$ & $\begin{array}{l}0.032 \\
0.037\end{array}$ & $\begin{array}{l}0.048^{*} \\
0.022\end{array}$ & $\begin{array}{l}-0.031 \\
-0.033\end{array}$ \\
\hline BNZ & $\begin{array}{l}T_{\max } \\
T_{\min }\end{array}$ & $\begin{array}{l}0.039 \\
0.071^{* * *}\end{array}$ & $\begin{array}{l}0.088 \\
0.122^{*}\end{array}$ & $\begin{array}{l}0.094^{*} \\
0.102^{*}\end{array}$ & $\begin{array}{l}0.011 \\
0.056^{* *}\end{array}$ & $\begin{array}{r}-0.017 \\
0.024\end{array}$ \\
\hline CDR & $\begin{array}{l}T_{\max } \\
T_{\min }\end{array}$ & $\begin{array}{l}0.009 \\
0.026\end{array}$ & $\begin{array}{l}0.013 \\
0.029\end{array}$ & $\begin{array}{l}0.042 \\
0.052^{*}\end{array}$ & $\begin{array}{l}0.004 \\
0.033^{*}\end{array}$ & $\begin{array}{l}-0.028 \\
-0.012\end{array}$ \\
\hline SGS & $\begin{array}{l}T_{\max } \\
T_{\min }\end{array}$ & $\begin{array}{l}0.079^{* * *} \\
0.116^{* * *}\end{array}$ & $\begin{array}{l}0.006 \\
0.105^{* * *}\end{array}$ & $\begin{array}{l}0.118^{* * *} \\
0.153^{* * *}\end{array}$ & $\begin{array}{l}0.113^{* * *} \\
0.101^{* * *}\end{array}$ & $\begin{array}{l}0.083 \\
0.110^{* * *}\end{array}$ \\
\hline CWT & $\begin{array}{l}T_{\max } \\
T_{\min }\end{array}$ & $\begin{array}{l}0.01 \\
0.033^{* *}\end{array}$ & $\begin{array}{l}0.004 \\
0.025\end{array}$ & $\begin{array}{l}0.014 \\
0.026\end{array}$ & $\begin{array}{l}0.016 \\
0.027^{* *}\end{array}$ & $\begin{array}{r}-0.003 \\
0.041\end{array}$ \\
\hline HBR & $\begin{array}{l}T_{\max } \\
T_{\min }\end{array}$ & $\begin{array}{l}0.006 \\
0.019\end{array}$ & $\begin{array}{l}0.025 \\
0.037\end{array}$ & $\begin{array}{l}0.012 \\
0.029\end{array}$ & $\begin{array}{c}-0.02 \\
0.006\end{array}$ & $\begin{array}{l}-0.003 \\
-0.003\end{array}$ \\
\hline HFR & $\begin{array}{l}T_{\max } \\
T_{\min }\end{array}$ & $\begin{array}{l}0.050^{* * *} \\
0.019\end{array}$ & $\begin{array}{l}0.064 \\
0.026\end{array}$ & $\begin{array}{l}0.059^{* *} \\
0.019\end{array}$ & $\begin{array}{l}0.036 \\
0.022\end{array}$ & $\begin{array}{r}0.031 \\
-0.001\end{array}$ \\
\hline JRN & $\begin{array}{l}T_{\max } \\
T_{\min }\end{array}$ & $\begin{array}{c}-0.038^{* * *} \\
0.040^{*}\end{array}$ & $\begin{array}{r}-0.034 \\
0.031\end{array}$ & $\begin{array}{c}-0.042^{* *} \\
0.024\end{array}$ & $\begin{array}{r}-0.043^{*} \\
0.054^{*}\end{array}$ & $\begin{array}{c}-0.039^{*} \\
0.049\end{array}$ \\
\hline KBS & $\begin{array}{l}T_{\max } \\
T_{\min }\end{array}$ & $\begin{array}{r}-0.024 \\
0.018\end{array}$ & $\begin{array}{l}-0.04 \\
0\end{array}$ & $\begin{array}{l}-0.022 \\
-0.011\end{array}$ & $\begin{array}{r}-0.007 \\
0.027\end{array}$ & $\begin{array}{r}-0.027 \\
0.049\end{array}$ \\
\hline KNZ & $\begin{array}{l}T_{\max } \\
T_{\min }\end{array}$ & $\begin{array}{l}0.022 \\
0.022^{*}\end{array}$ & $\begin{array}{l}0.02 \\
0.027\end{array}$ & $\begin{array}{l}0.032 \\
0.038\end{array}$ & $\begin{array}{l}0.023 \\
0.029\end{array}$ & $\begin{array}{l}0.008 \\
0.015\end{array}$ \\
\hline LUQ & $\begin{array}{l}T_{\max } \\
T_{\min }\end{array}$ & $\begin{array}{r}0.01 \\
-0.01\end{array}$ & $\begin{array}{r}0.006 \\
-0.023\end{array}$ & $\begin{array}{r}0.002 \\
-0.026\end{array}$ & $\begin{array}{c}0.021^{* *} \\
-0.004\end{array}$ & $\begin{array}{l}0.012 \\
0.012\end{array}$ \\
\hline $\mathrm{MCM}^{\mathrm{a}}$ & $\begin{array}{l}T_{\max } \\
T_{\min }\end{array}$ & $\begin{array}{c}0.044^{*} \\
-0.01\end{array}$ & $\begin{array}{r}0.025 \\
-0.041\end{array}$ & $\begin{array}{l}0.334^{* *} \\
0.339^{* * *}\end{array}$ & $\begin{array}{l}-0.184^{* * *} \\
-0.243^{* * *}\end{array}$ & $\begin{array}{l}0.026 \\
-0.06\end{array}$ \\
\hline NTL & $\begin{array}{l}T_{\max } \\
T_{\min }\end{array}$ & $\begin{array}{l}-0.031^{*} \\
-0.004\end{array}$ & $\begin{array}{l}-0.034 \\
-0.003\end{array}$ & $\begin{array}{r}-0.014 \\
0.018\end{array}$ & $\begin{array}{r}-0.021 \\
0.002\end{array}$ & $\begin{array}{l}-0.058 \\
-0.036\end{array}$ \\
\hline NWT & $\begin{array}{l}T_{\max } \\
T_{\min }\end{array}$ & $\begin{array}{l}-0.014 \\
-0.025\end{array}$ & $\begin{array}{l}-0.02 \\
-0.034\end{array}$ & $\begin{array}{l}0.004 \\
0.006\end{array}$ & $\begin{array}{r}0.001 \\
-0.013\end{array}$ & $\begin{array}{l}-0.04 \\
-0.056^{*}\end{array}$ \\
\hline SEV & $\begin{array}{l}T_{\max } \\
T_{\min }\end{array}$ & $\begin{array}{c}0.028^{* *} \\
-0.011\end{array}$ & $\begin{array}{r}0.032 \\
-0.034\end{array}$ & $\begin{array}{l}0.038 \\
0.068^{* * *}\end{array}$ & $\begin{array}{l}0.012 \\
0.001\end{array}$ & $\begin{array}{c}0.032 \\
-0.073^{* *}\end{array}$ \\
\hline VCR & $\begin{array}{l}T_{\max } \\
T_{\min }\end{array}$ & $\begin{array}{l}0.019 \\
0.035\end{array}$ & $\begin{array}{l}0.007 \\
0.043\end{array}$ & $\begin{array}{l}0.007 \\
0.022\end{array}$ & $\begin{array}{l}0.024 \\
0.033^{*}\end{array}$ & $\begin{array}{l}0.024 \\
0.03\end{array}$ \\
\hline \multicolumn{7}{|c|}{${ }^{a}$ Period is $1957-1987$} \\
\hline
\end{tabular}

partly offset or overridden by increased water demand from increased potential evapotranspiration. Elevated temperatures will also affect soil biogeochemical processes altering soil carbon storage and nitrogen availability (VEMAP Members 1995, Epstein et al. 1997).

Precipitation values show both increasing and decreasing trends, with the median value for all sites displaying a slight increase of about $2 \mathrm{~mm} \mathrm{yr}^{-1}$ (Table 5). Significant increases in annual precipitation are shown at HFR, JRN, NWT, and KBS, while a significant decrease is found at ARC. A seemingly large increase at LUQ is not statistically significant because of the large annual amount of precipitation at the site. Presentation of these data as a percentage of change for the period 1957-1990 allows a more direct comparison among the sites irrespective of their absolute values of precipitation. These calculations were made by multiplying the slope value (Table 5) by the number of years, dividing by the mean for the 1957-1990 period, and multiplying by 100 . Such a comparison (Table 6) shows some quite large changes ranging from -44 to $+49 \%$ for annual precipitation. The median change in annual precipitation across all sites is $14 \%$. Some of the larger changes such as for the ARC and JRN sites relate to high change and variability around a relatively low mean value. Such changes may have potentially important ecological effects.

\subsection{Trends: longest available period}

Trends for the common period are put in a better long-term perspective by the comparable values for the longest record data setespecially for those sites which have records markedly longer than the $34 \mathrm{yr}$ common period. The 8 sites with longer records are BNZ (42 yr), CWT (56 yr), HFR (67 yr), JRN (76 yr), KNZ (101 yr), LUQ (62 yr), NTL (88 yr), and SEV (96 yr). Except for BNZ, none of the sites listed here had outstandingly large trends in the common period. This is not unexpected because existing trends found by specialized studies have been very small. For example, a trend in mean annual temperature over 117 yr for eastern Minnesota, which provides context for the CDR

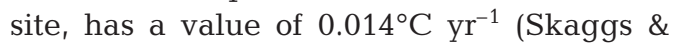
Baker 1989). An earlier study of long-term SGS trends (1912-1987) using mulitple stations found a significant positive trend in annual mean temperature $\left(+0.028^{\circ} \mathrm{C} \mathrm{yr}^{-1}\right)$ 
Table 5. Trends in precipitation $\left(\mathrm{mm} \mathrm{yr}^{-1}\right)$ for annual and seasonal values over the period 1957-1990. Significance: ${ }^{*} p<0.05,{ }^{* *} p<0.01,{ }^{* * *} p<$ 0.001 . Significance values were not computed for the winter water year (WWY) trends

\begin{tabular}{|lcrllrl|}
\hline Site & Annual & WWY & Winter & Spring & Summer & Fall \\
\hline AND & -4.259 & -4.519 & -3.366 & -0.566 & 1.531 & -0.999 \\
ARC & $-1.541^{*}$ & -1.459 & $-0.442^{* *}$ & $-0.518^{*}$ & 0.106 & $-0.674^{*}$ \\
BNZ & 0.820 & -0.228 & -0.247 & -0.080 & 0.551 & 0.339 \\
CDR & 2.739 & 1.372 & 0.028 & -0.036 & 1.640 & 1.218 \\
SGS & 0.424 & 0.917 & 0.174 & 0.105 & -0.206 & 0.240 \\
CWT & -3.497 & -2.125 & -1.384 & -0.430 & -2.874 & 0.545 \\
HBR & 5.908 & 0.424 & -0.573 & $3.023^{*}$ & 2.726 & 0.489 \\
HFR & $8.817^{* *}$ & 4.397 & 0.666 & $3.871^{*}$ & 1.876 & 1.946 \\
JRN & $2.648^{*}$ & 1.790 & 0.293 & $1.112^{* *}$ & 0.472 & $1.095^{*}$ \\
KBS & $9.590^{* * *}$ & 5.852 & $2.407^{*}$ & $2.476^{*}$ & 0.432 & $4.564^{* * *}$ \\
KNZ & 0.663 & 2.594 & 0.355 & 1.358 & -0.883 & -0.179 \\
LUQ & 17.104 & 13.216 & 4.390 & 4.876 & -0.492 & 8.507 \\
MCM & 0.089 & & 0.261 & -0.069 & -0.811 & 0.780 \\
NTL & 2.075 & 2.728 & 0.539 & 0.336 & -0.480 & 1.819 \\
NWT & $13.614^{* *}$ & 13.395 & $4.079^{*}$ & $6.019^{* * *}-0.710$ & $4.343^{* *}$ \\
SEV & 2.027 & 0.338 & 0.438 & -0.025 & 1.099 & 0.611 \\
VCR & -2.119 & -0.729 & 0.073 & -0.455 & -0.650 & -0.977 \\
aperiod is $1957-1987$ & & & & \\
\hline
\end{tabular}

values is statistically significant, there are 18 cases where the trend for the minimum temperature exceeds that for the maximum temperature compared with 13 where the reverse is true. In cases of paired maximum and minimum temperature trends for a season and site where the trend in both of the pairs of values is statistically significant, there are 7 cases where the trend for the minimum temperature exceeds that for the maximum temperature compared with 9 where the reverse is true. Thus temperature values for the longer records at LTER sites do not provide unequivocal evidence to support the suggestion of a greater increase in minima compared to maxima temperatures.

Trends in precipitation values for the 8 sites with the longest records discussed above identify increases at CWT in the fall (2.497 $\left.\mathrm{mm} \mathrm{yr}^{-1}, \mathrm{p}<0.05\right)$, at JRN for the year $\left(0.994 \mathrm{~mm} \mathrm{yr}^{-1}, \mathrm{p}<0.05\right)$, at KNZ in the fall (2.497 $\left.\mathrm{mm} \mathrm{yr}^{-1}, \mathrm{p}<0.05\right)$, and at LUQ in the winter $\left(2.897 \mathrm{~mm} \mathrm{yr}^{-1}, \mathrm{p}<0.05\right)$, and a slight decrease at $\mathrm{SEV}$ in the spring $(-0.242 \mathrm{~mm}$

and no significant trend in annual precipitation (Kittel 1990). The results in the present analysis (Table 7 , Fig. 3) display examples of both trends that are sustained and trends that are reversed between the common data period (1957-1990) and the longest data period for a site. Only statistically significant trends are discussed here.

Among the 8 sites with longer term data, more of them display positive rather than negative trends, and the positive trends tend to be larger than the negative trends (Fig. 3). The large positive values in the trends at the BNZ site in Alaska are consistent with many studies indicating warming at high latitudes (e.g. Ruddiman 2000, p. 375). Upward trends in temperatures have had important ecological effects at BNZ as well as at PAL, discussed in Section 4. Trends in maximum temperatures for the longer periods show the appearance of some new significant trends, such as particularly strong trends at BNZ and at LUQ, and the strengthening of already identified trends such as at HFR. The annual JRN maximum temperature value changes to a positive $0.002^{\circ} \mathrm{C} \mathrm{yr}^{-1}$ (not significant) for the longer $76 \mathrm{yr}$ record, although the summer and annual mean temperature trends remain negative.

With respect to all the longest available records, including both significant and non-significant values, only $52 \%$ of the seasonal values from all sites show a more positive trend value for minimum temperatures compared with maximum temperatures. In cases of paired maximum and minimum temperature trends for a season and site where the trend in one of the pairs of $\left.\mathrm{yr}^{-1}, \mathrm{p}<0.05\right)$. There were no statistically significant trends in precipitation in the longest period data at BNZ, HFR and NTL. The median value of all LTER sites for percentage changes in precipitation, both significant and non-significant, since the beginning of the individual records are all positive except for the summer season. These results find general support in the analysis of Karl et al. (1996).

Table 6. Percentage change in precipitation for annual and seasonal values over the period 1957-1990

\begin{tabular}{|lcrrrrr|}
\hline Site & Annual & WWY & Winter & Spring & Summer & Fall \\
\hline AND & -7 & -8 & -12 & -4 & 46 & -6 \\
ARC & 44 & -117 & -112 & -129 & 6 & -63 \\
BNZ & 10 & -8 & -20 & -9 & 15 & 17 \\
CDR & 12 & 18 & 1 & -1 & 18 & 22 \\
SGS & 4 & 40 & 32 & 3 & -5 & 14 \\
CWT & -7 & -6 & -9 & -3 & -25 & 4 \\
HBR & 15 & 2 & -6 & 33 & 28 & 5 \\
HFR & 28 & 25 & 9 & 49 & 22 & 25 \\
JRN & 35 & 83 & 34 & 133 & 11 & 66 \\
KBS & 19 & 45 & 45 & 46 & 6 & 60 \\
KNZ & 3 & 27 & 17 & 19 & -10 & -3 \\
LUQ & 24 & 35 & 33 & 28 & -3 & 36 \\
MCM & 2 & & 18 & -6 & -57 & 53 \\
NTL & 9 & 32 & 23 & 6 & -5 & 28 \\
NWT & 49 & 72 & 52 & 66 & -14 & 75 \\
SEV & 28 & 12 & 41 & -3 & 39 & 25 \\
VCR & -7 & -4 & 1 & -6 & -7 & -14 \\
Median & 12 & 21 & 17 & 3 & 6 & 22 \\
aPeriod is $1957-1987$ & & & & \\
\end{tabular}


Overall we find that there are significant trends in the climate record of some, but not all, sites. Also it is common for the trends to appear in some seasons and not in others. For the shorter, common period record, which commences in 1957, annual mean temperatures at almost all sites have slightly increasing values. Significant increases are seen in annual values at BNZ, CWT, HRF and VCR. The maximum decrease in annual mean temperature trends is found at NWT. We conclude that there is not enough evidence to assess the century-long temperature trends across the sites. In summary it is likely that there has been warming and a slight increase in precipitation at most LTER sites over the period of record, and this likelihood has increased in the $30 \mathrm{yr}$ preceding 1990.

\subsection{Step functions}

Studies of interdecadal variation of climate have identified step functions in climatic records (Trenberth \& Hurrell 1994, Mantua et al. 1996). It appears as if the climate will operate in one mode for a number of years and then will change to another mode and later switch back again. One of the most marked of these step functions in recent time, at least for the North Pacific and

Table 7. Trends in temperature using longest available records at selected LTER sites

\begin{tabular}{|c|c|c|c|c|c|c|}
\hline Site & $\begin{array}{l}\text { Years of } \\
\text { record }\end{array}$ & $\begin{array}{l}\text { Length of } \\
\text { record (yr) }\end{array}$ & Variable & $\begin{array}{l}\text { Annual or } \\
\text { season }\end{array}$ & $\begin{array}{c}\text { Trend } \\
\left({ }^{\circ} \mathrm{C}_{\mathrm{yr}^{-1}}\right)\end{array}$ & Significance \\
\hline BNZ & 1952-1994 & 42 & $\begin{array}{l}T_{\text {mean }} \\
T_{\max } \\
T_{\max } \\
T_{\max } \\
T_{\max }\end{array}$ & $\begin{array}{l}\text { Annual } \\
\text { Annual } \\
\text { Winter } \\
\text { Spring } \\
\text { Summer }\end{array}$ & $\begin{array}{l}0.062 \\
0.054 \\
0.11 \\
0.072 \\
0.046\end{array}$ & $\begin{array}{l}p<0.001 \\
p<0.01 \\
p<0.01 \\
p<0.05 \\
p<0.05\end{array}$ \\
\hline CWT & 1936-1994 & 56 & $\begin{array}{l}T_{\max } \\
T_{\max }\end{array}$ & $\begin{array}{l}\text { Annual } \\
\text { Fall }\end{array}$ & $\begin{array}{l}-0.01 \\
-0.016\end{array}$ & $\begin{array}{l}\mathrm{p}<0.05 \\
\mathrm{p}<0.05\end{array}$ \\
\hline HFR & 1949-1994 & 67 & $\begin{array}{l}T_{\max } \\
T_{\min } \\
T_{\max } \\
T_{\max } \\
T_{\max } \\
T_{\max }\end{array}$ & $\begin{array}{l}\text { Annual } \\
\text { Annual } \\
\text { Winter } \\
\text { Spring } \\
\text { Summer } \\
\text { Fall }\end{array}$ & $\begin{array}{r}0.019 \\
-0.015 \\
0.024 \\
0.028 \\
0.012 \\
0.012\end{array}$ & $\begin{array}{l}p<0.01 \\
p<0.01 \\
p<0.01 \\
p<0.001 \\
p<0.01 \\
p<0.05\end{array}$ \\
\hline JRN & $1917-1993$ & 76 & $\begin{array}{l}T_{\text {mean }} \\
T_{\min } \\
T_{\min } \\
T_{\text {mean }} \\
T_{\text {min }} \\
T_{\text {min }}\end{array}$ & $\begin{array}{l}\text { Annual } \\
\text { Annual } \\
\text { Winter } \\
\text { Summer } \\
\text { Summer } \\
\text { Fall }\end{array}$ & $\begin{array}{l}-0.007 \\
-0.016 \\
-0.018 \\
-0.013 \\
-0.02 \\
-0.016\end{array}$ & $\begin{array}{l}p<0.05 \\
p<0.01 \\
p<0.05 \\
p<0.01 \\
p<0.01 \\
p<0.05\end{array}$ \\
\hline KNZ & $1892-1993$ & 101 & $\begin{array}{l}T_{\max } \\
T_{\min } \\
T_{\min } \\
T_{\min }\end{array}$ & $\begin{array}{l}\text { Fall } \\
\text { Annual } \\
\text { Spring } \\
\text { Summer }\end{array}$ & $\begin{array}{c}-0.014 \\
0.009 \\
0.05 \\
0.012\end{array}$ & $\begin{array}{l}p<0.01 \\
p<0.01 \\
p<0.01 \\
p<0.01\end{array}$ \\
\hline LUQ & 1932-1994 & 62 & $\begin{array}{l}T_{\text {mean }} \\
T_{\operatorname{mean}} \\
T_{\max } \\
T_{\min } \\
T_{\max } \\
T_{\max } \\
T_{\max } \\
T_{\max }\end{array}$ & $\begin{array}{l}\text { Annual } \\
\text { Fall } \\
\text { Annual } \\
\text { Annual } \\
\text { Winter } \\
\text { Spring } \\
\text { Summer } \\
\text { Fall }\end{array}$ & $\begin{array}{r}0.007 \\
0.011 \\
0.024 \\
-0.009 \\
0.023 \\
0.027 \\
0.022 \\
0.023\end{array}$ & $\begin{array}{l}p<0.05 \\
p<0.01 \\
p<0.001 \\
p<0.01 \\
p<0.001 \\
p<0.001 \\
p<0.001 \\
p<0.001\end{array}$ \\
\hline NTL & 1906-1994 & 88 & $\begin{array}{l}T_{\operatorname{mean}} \\
T_{\max } \\
T_{\min } \\
T_{\operatorname{mean}} \\
T_{\min }\end{array}$ & $\begin{array}{l}\text { Summer } \\
\text { Summer } \\
\text { Summer } \\
\text { Fall } \\
\text { Fall }\end{array}$ & $\begin{array}{l}-0.013 \\
-0.013 \\
-0.013 \\
-0.014 \\
-0.017\end{array}$ & $\begin{array}{l}p<0.05 \\
p<0.05 \\
p<0.05 \\
p<0.05 \\
p<0.01\end{array}$ \\
\hline SEV & 1898-1994 & 96 & $\begin{array}{l}T_{\text {mean }} \\
T_{\min } \\
T_{\text {mean }} \\
T_{\max } \\
T_{\min }\end{array}$ & $\begin{array}{l}\text { Spring } \\
\text { Spring } \\
\text { Summer } \\
\text { Summer } \\
\text { Summer }\end{array}$ & $\begin{array}{c}0.013 \\
0.009 \\
0.011 \\
-0.013 \\
0.02\end{array}$ & $\begin{array}{l}p<0.001 \\
p<0.05 \\
p<0.001 \\
p<0.001 \\
p<0.001\end{array}$ \\
\hline
\end{tabular}


Significant Trends in Temperature for Longest Period Data

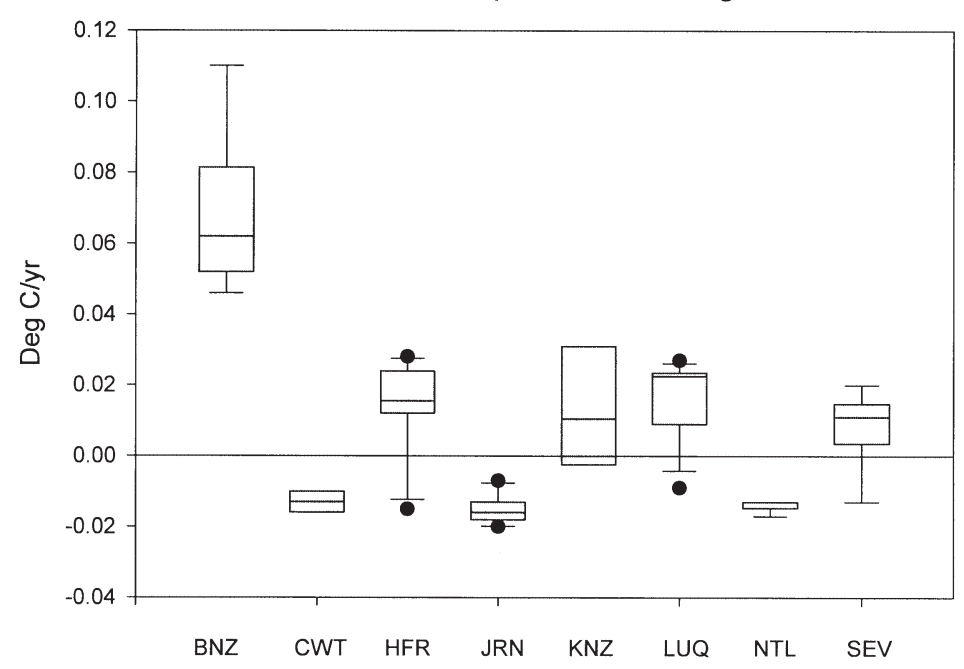

Fig. 3. Box plot of annual and seasonal mean, maximum and minimum temperature trends for temperature trends that are statistically significant in the longest period data sets

NW North America, has been the change that took place around 1976 (Ebbesmeyer et al. 1991). This has now come to be recognized as being part of the Pacific Decadal Oscillation (PDO) (Mantua et al. 1996). We tested our data set for the existence of this step function. We averaged the standardized anomalies of the data from each regional group of sites. Student's $t$-tests were performed for the average of each group of sites and for each variable by year and season on the $14 \mathrm{yr}$ before and after 1976. Specifically we used a 2-tailed test to inquire if the means of values in the period 1963-1976 are significantly different from the means in the period 1977-1990. We chose 14 yr periods because longer periods might contain influences of an earlier or later decadal climate regime shift and 1990 was the end of the common data set. The results indicated that the 1976 step function was detectable in several of the LTER groups and in different seasons (Table 8). The step function was strongest in the temperature records of the Alaska and PNW region, where it was first discovered. Separate $t$-tests were performed for AND and BNZ because the winter climates of the 2 sites tend to respond in opposite ways to the climatic modes that form this step. Only the AND site showed notable changes in mean annual and winter season temperatures and winter precipitation. Important ecological effects of these changes are discussed in Section 4. The North Central group of sites experienced the step function in its summer rainfall values. This might have significant effects on the ecosystems of the sites in this group. We further note that in the discussions of the detrended standardized anomalies below, the mid-1970s appears as a point at which climate trends change for some sites. The Alaska/PNW group is a case in point. This is to be expected in light of recent discoveries identifying the operation of the PDO (Mantua et al. 1996).

\subsection{Five year moving averages of detrended standardized anomalies}

Five year moving averages for the 4 variables for the common period and longest record were made of the detrended standardized data. The $30 \mathrm{yr}$ or longer linear trends that were removed are those described and analyzed in the previous section. The removal was performed so that decadal-scale variability tends to be emphasized over trends. In the following (see Sections 3.5 and 3.6) we provide an overview of the results from groups of sites. A similar detrending and standardization and creation of moving averages of the data would be appropriate if LTER biological data are to be compared directly to the climate data results presented here. The TI data that are compared below to some of the temperature and precipitation data were also made into 5 yr moving averages and standardized where necessary, but they were not detrended. Graphs were plotted of $5 \mathrm{yr}$ moving

Table 8. Significance values from $t$-tests for difference of means between 1963-1976 and 1977-1990. Only significance levels of 0.20 or better are quoted. A\&PNW: Alaska and Pacific North West; NCENT: North Central; ECOAST: East Coast; CGs\&SW: Central Grasslands and South West

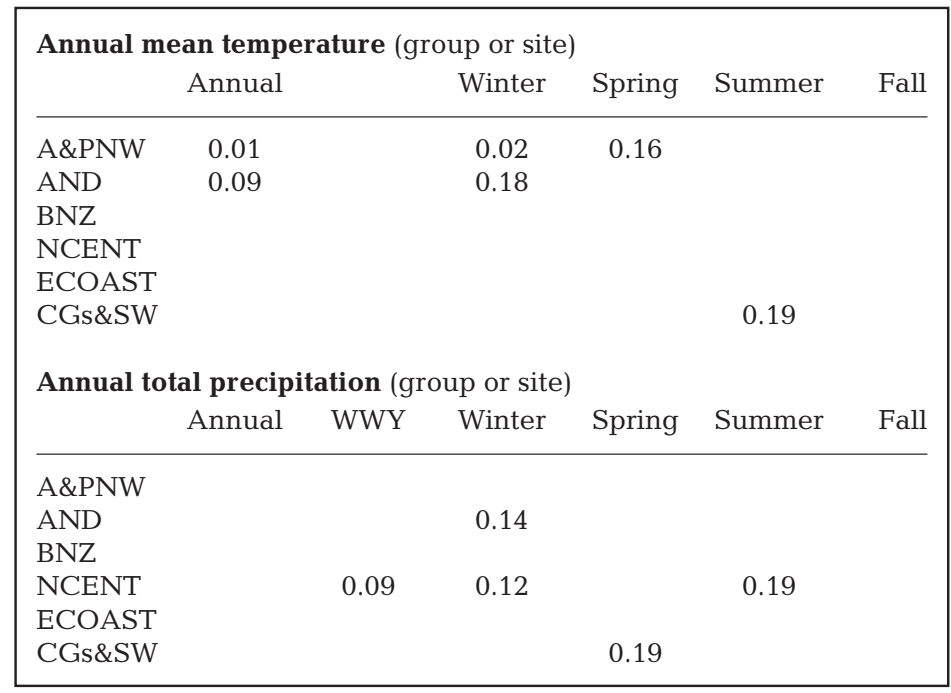


averages of standardized anomalies and TI for annual average, winter average, and summer average values in order to identify any correspondences. With 3 exceptions, these graphs are not shown in this paper, but the comments below are derived from them. No correspondences were seen between any of the variables for the summer months. We only examine visual correspondences as opposed to quantitative relations. We take this approach because the moving-average techniques add autocorrelation to the data sets. The new autocorrelation, in addition to any that already existed, violates background assumptions to most statistical correlation procedures. Only the common period data and annual values of mean temperature and total precipitation were examined in this part of the study in order to insure direct comparability.

\subsection{Temperature anomalies by group}

\subsubsection{North Central}

The mean annual temperature variations at most of the 4 sites operate together in the common period (1957-1990), especially after 1973, when values fall together until 1980, and all values generally rise together

a) North Central

\begin{tabular}{|ll|}
\hline- & CDR \\
$\cdots \cdots$ & NTL \\
-- & KBS \\
$-\cdots$ & KNZ \\
\hline
\end{tabular}

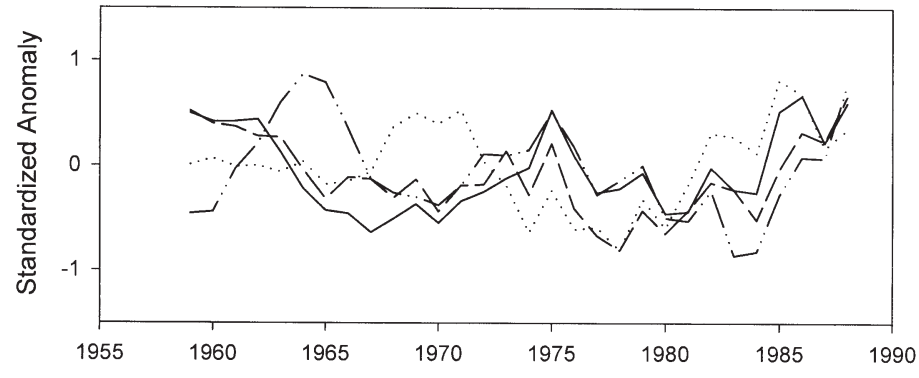

b) East Coast

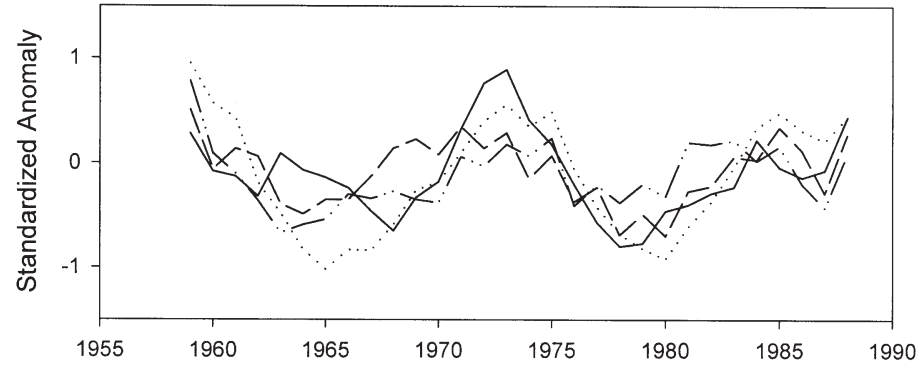

c) Central Grasslands \& South West
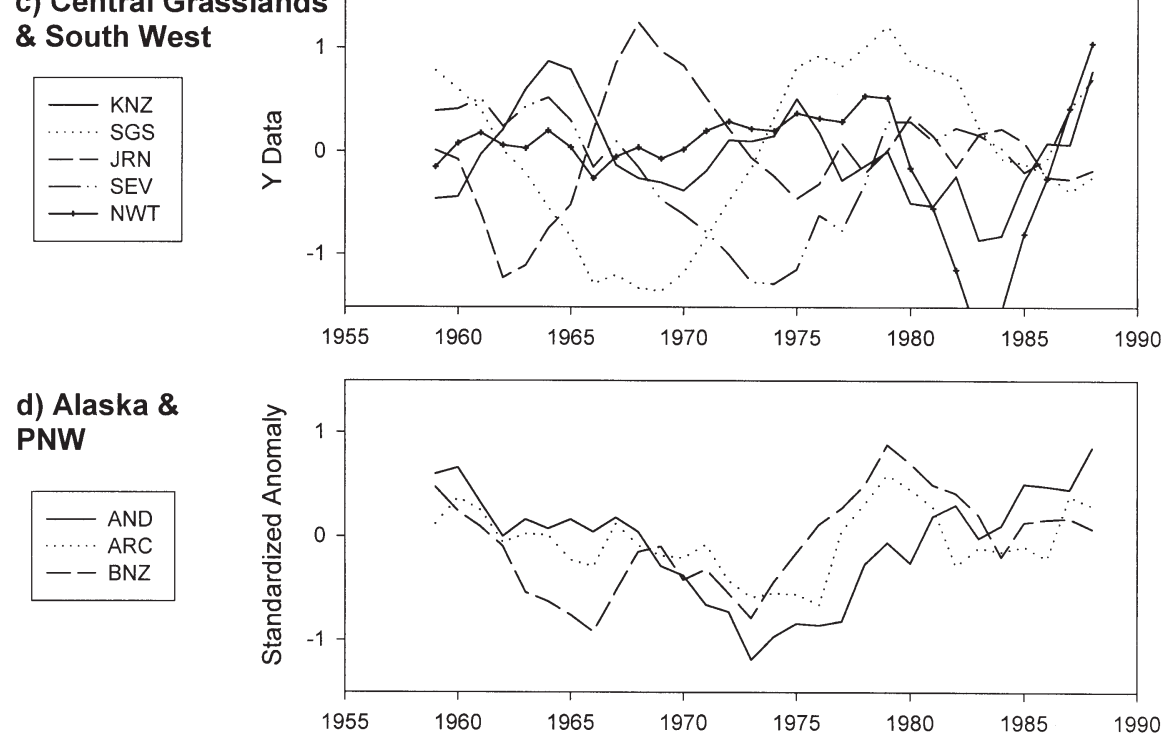

Fig. 4. (Above and facing page.) Detrended standardized anomalies of annual temperature (STA) at groups of LTER sites and corresponding teleconnective index values 

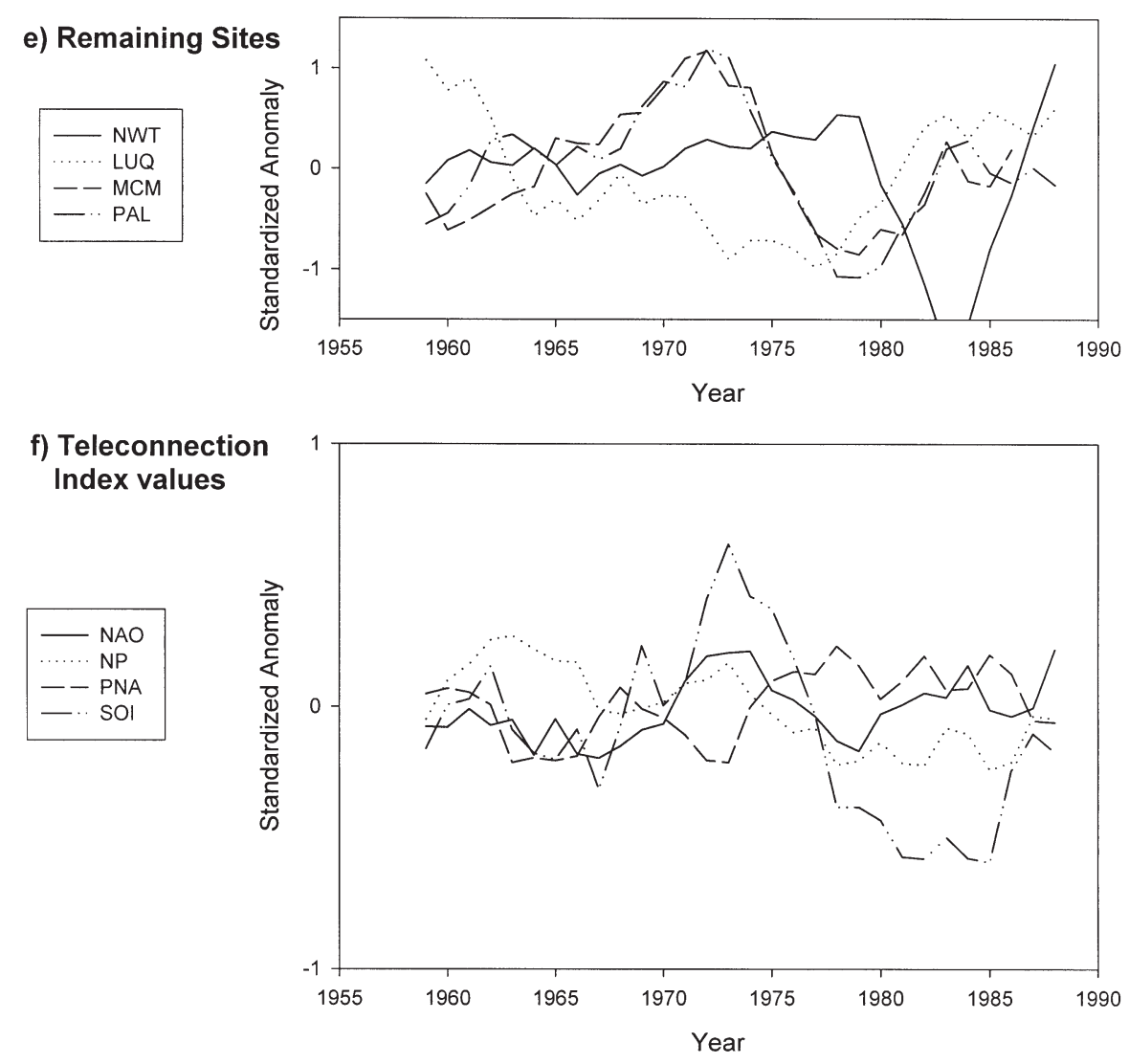

Fig. 4 (continued)

after that time (Fig. 4a). Previous to 1973 values at KBS and CDR operate together, starting with a high value around 1960 and decreasing to low values in the late 1960s before rising again. KNZ is out of step, showing a high value in the mid-1960s. Similarly NTL shows a high value around 1970. During most of the period there is a correspondence between NAO values (Fig. 4f) and temperature values. This may be because there tends to be a more westerly airflow component over the North Central LTER sites during the positive phase of NAO. In contrast, during the negative NAO phase there tends to be a more northerly, although less strong, airflow component over the sites. The correspondence is even more marked in the winter months (DJF).

\subsubsection{East Coast}

East Coast annual standardized temperature anomalies (STAs) appear to act in an even more coherent way than the North Central ones (Fig. 4b). During the common period, the annual STAs at all 4 sites rise and fall together, showing high points around 1960, 1973, and 1985 and low values in the mid-1960s and late 1970s.
Interestingly these sites do not show warming throughout the 1980s because of a relatively cold period centered at 1987. Yet there is an overall warming trend from about 1979/80 to 1990 despite the decrease in values around 1987. Annual STAs show a strong direct correspondence with NAO values (Figs 4f \& 5) and the correspondence is even more marked in the winter months. This is possibly for the same reasons described above for the North Central LTER sites but in addition there are positive sea surface temperature anomalies off the East Coast when NAO is positive (Cayan 1992). There is also a correspondence between annual STAs in this area and SOI values from the early 1960s to the early $1980 \mathrm{~s}$. It is possible that there is reinforcement between the NAO and the SOI that leads to the resulting annual STA values. The association between STAs in both the North Central and East Coast LTER sites with NAO values is consistent with a pattern shown by Hurrell \& Van Loon (1997, their Fig. 6) for data composited between 1864 and 1994. Thus this synoptic association may be quite stable through time-a fact that might be helpful in the design of future long-term ecological experiments at these sites. 
East Coast Mean Annual Temperature and NAO

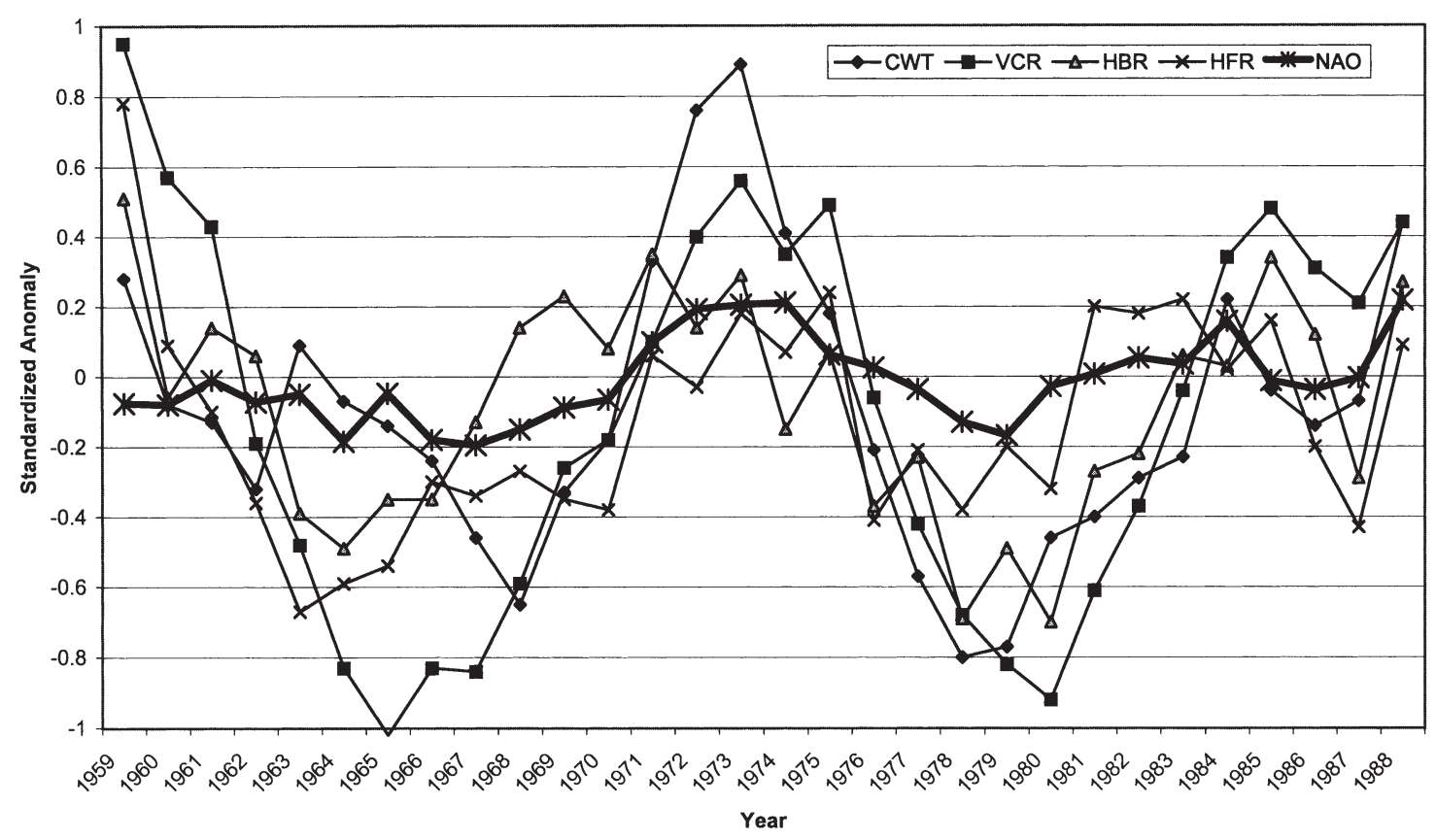

Fig. 5. Five year moving averages of standardized mean annual temperature anomalies for common period (1957-1990) at East Coast LTER sites compared to NAO values

\subsubsection{Central Grasslands and South West}

The Central Grassland and South West stations do not show any clear pattern in their annual temperature variation (Fig. 4c). STAs at SGS and KNZ are sometimes roughly in phase, while at other times they are out of phase. The STAs at the 2 New Mexico sites tend to be out of phase for the first part of the record up to about 1968 but then tend to vary together after that time. The STAs for NWT are decoupled from the rest of the group. Even though NWT is in close geographic proximity to SGS, the elevational difference of about $2100 \mathrm{~m}$ leads to the climates of the 2 locations being affected by different synoptic-scale processes. Extraordinary low STAs in the early 1980s are the main feature of the NWT alpine values. The minimum was first reported by Greenland (1989) and has been shown by M. Losleben (pers. comm.) to be found in other high elevation areas of the Rocky Mountains. No correspondence was noted between annual STAs and any of the TIs that were investigated.

\subsubsection{Alaska and PNW}

All 3 Alaska (ARC and BNZ) and the PNW (AND) sites have annual STAs which vary synchronously over the common period (Fig. 4d). STAs fall from about 1960 to about 1973 and then rise to about 1979. AND STAs continue to rise after that time while those at the other 2 sites fall to the mid-1980s before showing signs of rising again. The annual STAs of these sites show some direct correspondence with PNA values. Positive PNA values are consistent with warm air being advected northwards over these sites. The direct correspondence with PNA values is apparent even more for winter months (Fig. 6). Since the operations of the PNA and the NP tend to be related, it is not surprising that there is also a correspondence, though weaker, between winter STAs and NP values.

The Alaska PNW and East Coast STAs tend to be out of phase during the common data period. Particularly noticeable are the low STAs of the former area that occur when the East Coast is having a high peak in STAs. The phase difference is consistent with continental-scale planetary waves and the PNA teleconnective pattern, which would bring cold air to one region while bringing warmer air to the other. Dettinger et al. (1995) finds this change represented in a second empirical orthogonal function in an analysis of USHCN stations. Such a change provides the potential for the design of ecological experiments where above and below average temperatures are required simultaneously in different areas of the country. 


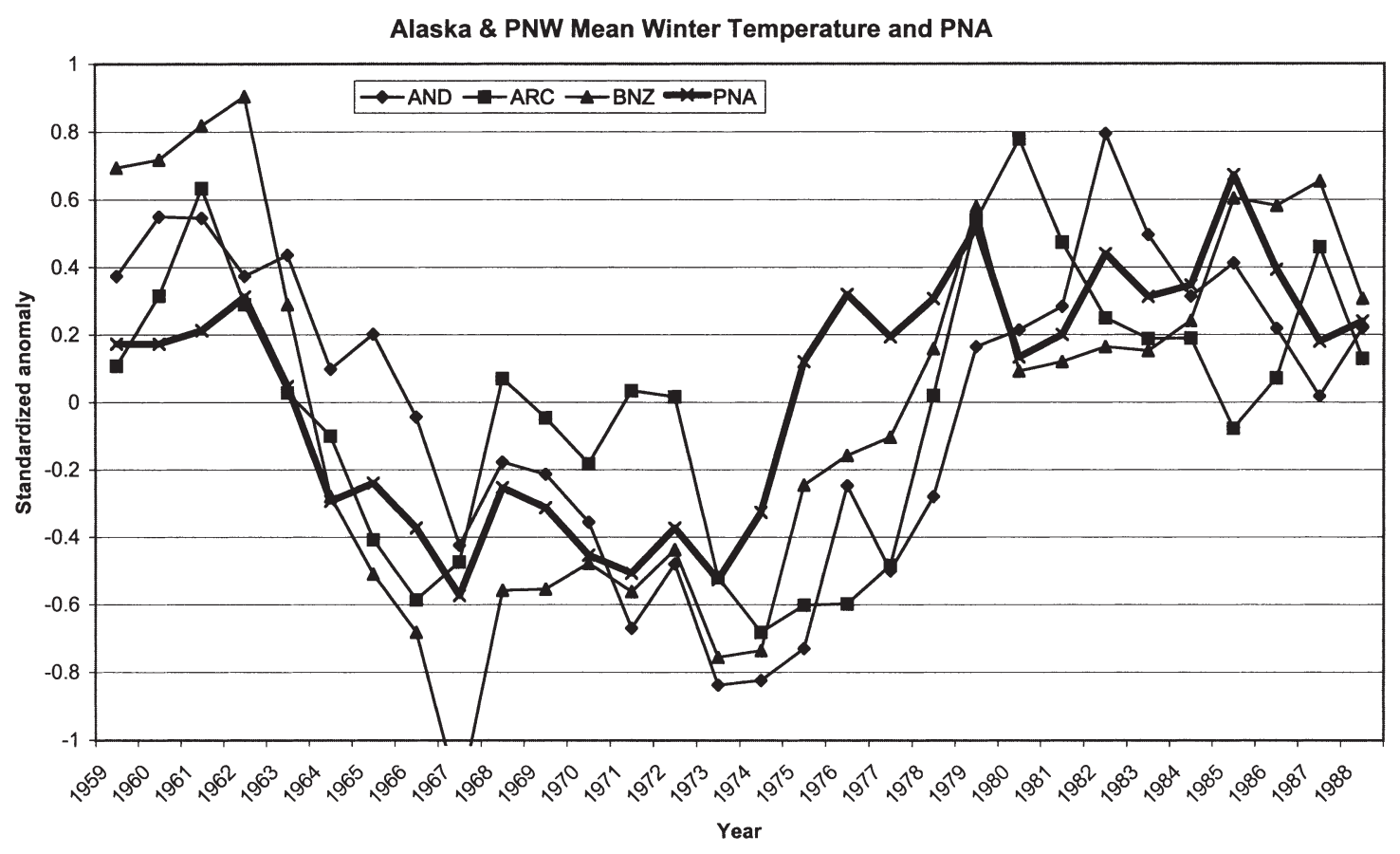

Fig. 6. Five-year moving averages of standardized winter mean temperature anomalies for common period (1957-1990) at Alaskan and Pacific Northwest LTER sites compared to PNA values

\subsubsection{Remaining sites}

Tropical, alpine and Antarctic sites have been placed in a remaining group (Fig. 4e). Despite being on opposite sides of the continent, the STAs at the 2 Antarctic sites show good correspondence, rising from the beginning of the common period to 1972 and falling to 1978 before rising again. This correspondence does not necessarily translate into a change of sea ice extent, which Stammerjohn \& Smith (1997) have shown to be opposite on the 2 sides of the Antarctic continent. This discrepancy may be due to the fact that detrended data are used in Fig. 4e but are not in the Stammerjohn \& Smith (1997) study. There is some evidence of correspondence between annual STAs at MCM and PAL and SOI, but this is not clear in the latter part of the period. LUQ shows a cooling from the beginning of the period to 1978 followed by a warming.

\subsection{Precipitation anomalies by group}

\subsubsection{North Central}

The annual standardized precipitation anomalies (SPA) values for the North Central LTER sites vary quite closely together (Fig. 7a). They show a minimum during the early 1960s, a maximum in the late 1960s followed by a decrease, for CDR and NTL, to a minimum in the mid1970s, which is reached later by KNZ (around 1980) and KBS (in the early 1980s). CDR, NTL, and KNZ have peak values centered on 1984 before values plunge in the late 1980s. The prime cause of this plunge is the 1988 drought. This drought has been noted by CDR investigators as having important effects on the ecosystem and its biodiversity (Tilman \& El Haddi 1992). The annual SPA values show some direct correspondence with NAO values, possibly because warmer westerly airflow can transport more precipitable water than the colder, more northerly air associated with negative NAO values. There appears to be no correspondence with the other TIs that were tested on an annual basis. During the winter months SPA values show quite a good correspondence with NAO values, except in the late 1960s.

\subsubsection{East Coast}

The precipitation annual anomaly values in the East Coast group vary closely together showing a minimum in the mid-1960s, a maximum in the mid-1970s (with VCR peaking a little later), and a minimum centered on 1986 (Fig. 7b). These results suggest a cycle of about 20 yr but again the record length is too short to be conclusive. Data from HRF (back to 1929) and HBR 
(back to 1951) tend to show some evidence of cycles. Values from CWT back to 1938 do not show much cyclic behavior. The drought of the mid-1960s in the NE gave rise to severe water shortages at the time. The drought in 1986 at CWT had effects lasting into 1988 and was extremely severe for the area (Swift et al. 1990). This drought gave rise to considerable tree mortality (W. Swank pers. comm. 1995). The annual SPA values, for the most part, display a direct relation with NAO values. The association is even better displayed in the winter month data (Fig. 8). This may be associated with the more zonal circulation at the time of positive NAO and the passage of storms though the area. No other TI values show noticeable correspondence with annual SPA values of precipitation for these sites.

\subsubsection{Central Grasslands and South West}

The SPA values at all 4 sites in this group do not vary together, but they do show interesting variations and values at KNZ, SEV, and JRN do display a tendency to vary together (Fig. 7c). The annual and winter month

a) North Central

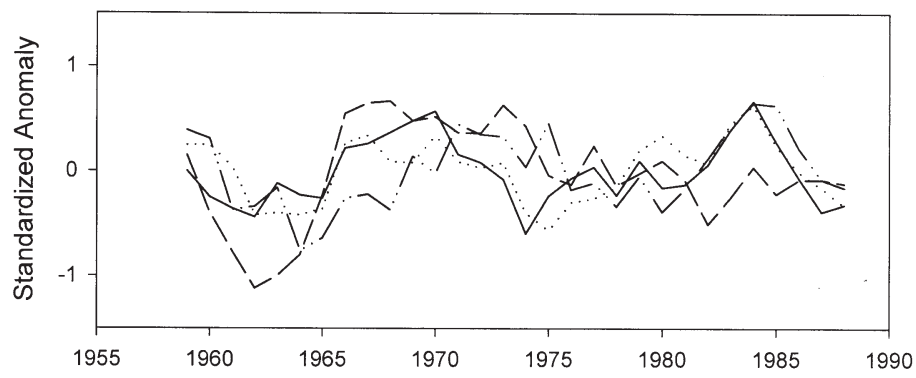

b) East Coast

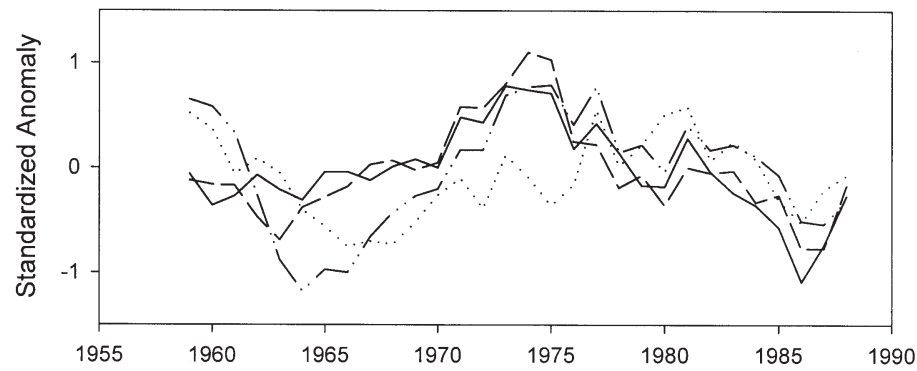

c) Central Grasslands \& South West

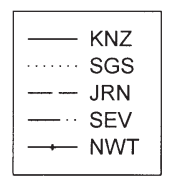

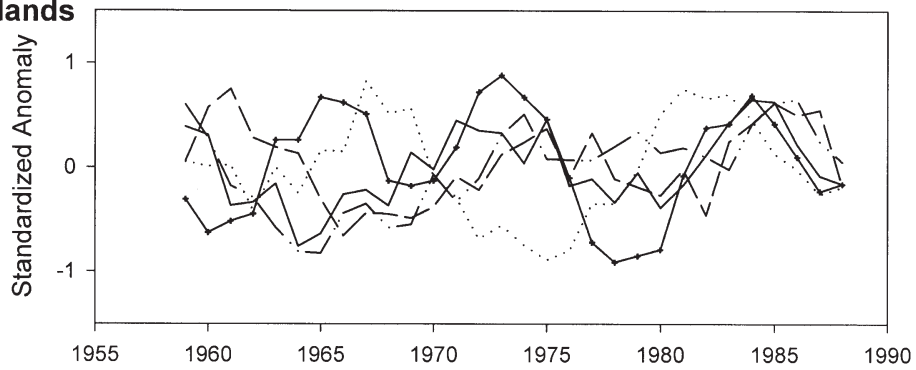

d) Alaska \& PNW
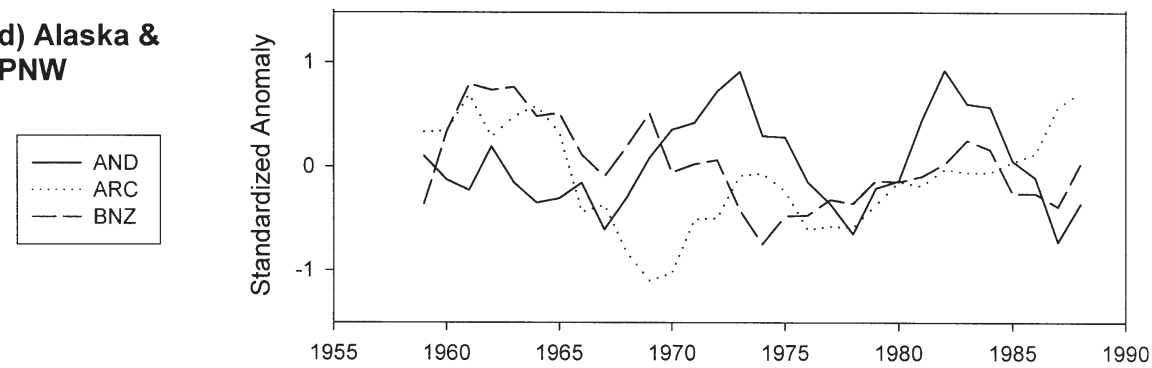

Fig. 7. (Above and facing page.) Detrended standardized anomalies of annual precipitation (STP) at groups of LTER sites and corresponding teleconnective index values 

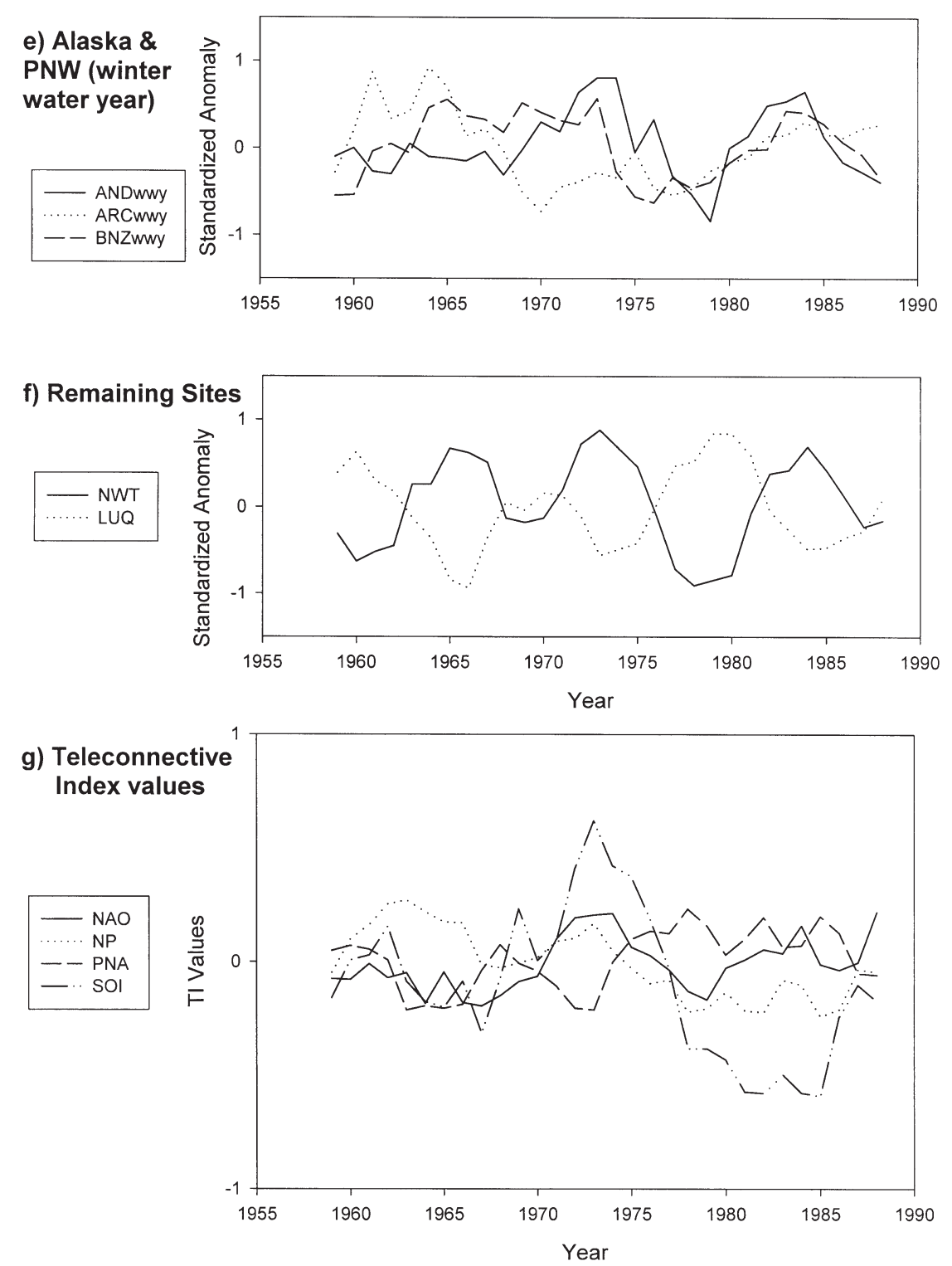

Fig. 7 (continued)

SPA values of precipitation at these sites do not show correspondence with TI values.

\subsubsection{Alaska and PNW}

Winter water year (October to the following April) values of SPA are also plotted for this group because at least for AND they are more meaningful in this area of winter precipitation maxima. The winter water year SPA values tend to vary together for the 2 Alaskan sites, ARC and BNZ, except in the late 1960s and early 1970s (Fig. 7e). Except for after 1977 the AND site SPAs do not seem to be related to the Alaskan SPA values. They show droughts centered at 1978 and 1987.
It is expected that the SPA values at ARC and AND should not vary together because they are under separate climatic regimes: the former site has a summer maximum and the latter site has a winter maximum of precipitation. However, these differences are somewhat masked when annual data are used for part of the analysis. Five-year moving-average means of winter water year SPA show a tendency for values at AND and BNZ to vary together, although there is some coherence between all 3 sites after the late 1970s. 1977, the year of a major shift in the PDO, appears as a behavioral breakpoint in these 3 time series. After 1977 the series appear to be more coherent than before. The annual SPA values of precipitation at these sites do not show correspondence with TI values. 


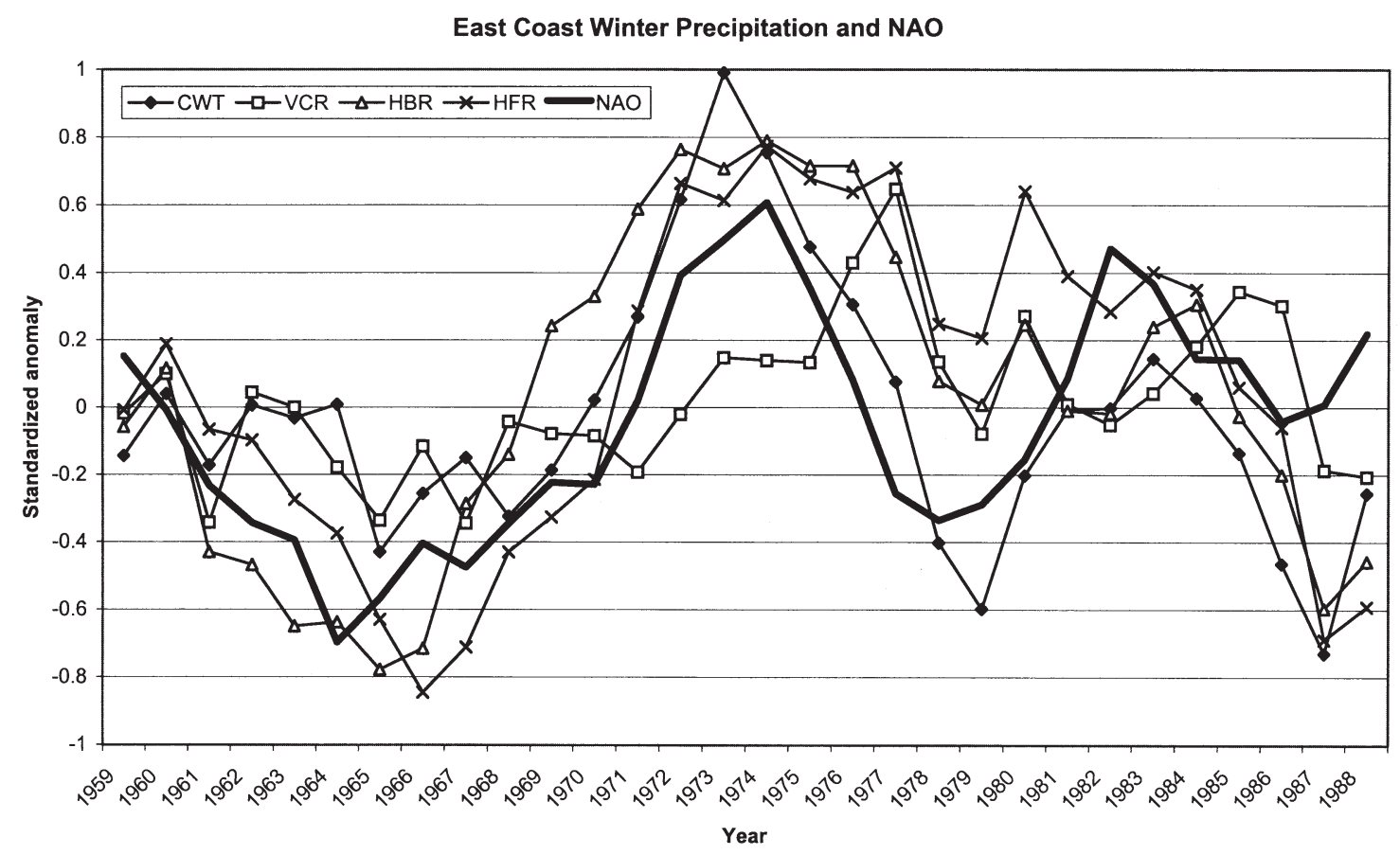

Fig. 8. Five-year moving averages of standardized winter total precipitation anomalies for common period (1957-1990) at East Coast LTER sites compared to NAO values

\subsubsection{Remaining sites}

There is a quite remarkable inverse behavior between the SPA values of the alpine NWT site and the tropical LUQ site with their 5 yr running mean annual SPA values varying almost entirely out of phase with one another (Fig. 7f). This apparent inverse relationship deserves more attention. There is a tendency for the times of higher than average annual precipitation at NWT to correspond with low PNA values (zonal flow), but it is difficult to see how the PNA values would be related to the annual SPA values of precipitation at the tropical site of LUQ. The inverse relationship does not exist in the winter SPA values after the mid-1970s, while in the summer months (JJA) SPA variations in the NWT record during the common data period tend to lead those at LUQ by about $4 \mathrm{yr}$.

In summary, these analyses confirm the belief that the climates of some groups of LTER sites, particularly those in the North Central and East Coast groups, tend to operate together over the common period between 1957 and 1990 as far as their annual STA and SPA values are concerned. The annual STA and SPA values of these 2 LTER site groups show correspondence with NAO values. Patterns among some of the other LTER sites are not as clear, but some, such as the Alaskan and PNW group, show interesting temporal variability and some correspondence with the larger synopticscale PNA TI.

\section{ECOLOGICAL IMPLICATIONS}

This analysis focuses on climate variability in the temporal scale of quasi-quintennial to interdecadal. Thus major ecosystem impacts from individual severe storms, such as hurricanes, or on the century scale, such as the Little Ice Age, and longer are not considered. There are still, however, many ecological implications at LTER sites within the time scales considered here.

Droughts acting as climatic episodes have been documented at LTER sites to have marked ecological effects. A study of the 1988 drought at the CDR site led LTER investigators to conclude that droughts could have a noticeable negative effect on species richness in grassland communities (Tilman \& El Haddi 1992, Tilman \& Downing 1994). The drought in 1986 at CWT and its cumulative effects for 2 yr afterwards was responsible for decreasing the number of pitch pine and oaks in the Coweeta basin (http://sparc.ecology.uga.edu/ webdocs/ongoing/html/rongap.html). Workers at the SEV site (Molles \& Dahm 1990, Dahm \& Molles 1992) have documented the effect of low streamflows during La Niña episodes and the ecological impact. Wetter than usual winters during El Niños have large effects on the aquatic and terrestrial ecosystems at SEV. Plant growth, invertebrates, rodents, and rabbits all react to the increase in autumn and spring moisture associated with El Niño. Additionally, Dahm \& Moore (1994) also showed that a series of dry La Niña episodes in the late 
1940s and mid-1950s led to significant die-back of pinyon pine and juniper at the site. Swetnam \& Betancourt (1998) used dendrochronology to demonstrate that on the decadal and century scales, changes of Southern Oscillation frequency and amplitude and rapid switching from one phase to another can have important effects on forest fire regimes and other ecological effects in the region around SEV.

Direct and fast responses between climate variability and the ecosystem should not always be expected, and the responses are manifested in different ways. At KNZ the 1983 El Niño and 1988 drought show up in annual net primary productivity (ANPP) data, although these climatic events are not so pronounced in precipitation values. At the KNZ site an index of ANPP, given by the difference between the maximum productivity and the mean productivity divided by the mean productivity, confirmed a good relation between precipitation and ANPP in general but not necessarily from year to year (Blair \& Shaver 1999). In addition, it was found that in some LTER ecosystems it took several years for the climate signal to work through to later be found in ANPP values.

Few studies have been made at LTER sites of episodes of above-average precipitation. One year, 1921, of extremely high precipitation in the Colorado alpine (NWT) was found to have little lasting effect on the ecosystem (Greenland 1995). However, in a more general context Lauenroth (1999) has pointed to a very close and simple relation for the SGS site and the Great Plains between annual precipitation and ANPP. He also found that annual precipitation values could explain $97 \%$ of the variance in net nitrogen mineralization. The relationships in the Great Plains are complicated because NPP values can also be affected by temperature and soil texture (Epstein et al. 1997).

At, and in the region of, BNZ during the 20th century, radial growth of white spruce on productive sites displays a strong negative correlation with summer temperature, which Barber et al. (2000) interpreted as a moisture stress signal partly related to the upward trend in temperature. The PAL site displays an interesting interaction between climate variations on different time scales. Smith et al. (1996) has noted that El Niño occurrence is associated with above-average ice extents in the Western Antarctic Peninsular area. Here the effect on the quasi-quintennial time scale somewhat offsets the strong warming trend that has been noted at this site over the last 40 to $50 \mathrm{yr}$. An important ecological linkage is associated with penguins in this location. Optimum sea ice conditions no longer exist for Adélie penguins in the Western Antarctic Peninsular because of the lack of sea ice due to long-term warming. In contrast, chinstrap penguin populations are increasing because they do better in open water conditions (Fraser et al. 1992). Thus, on the longer time scale of 5 decades, the smaller time scale El Niños give 'momentary' respite to the Adélie penguins at the expense of the chinstrap penguins, while La Niñas may have the opposite effect.

Step function changes in climate have also had important ecological effects at and near some LTER sites. Based on a variety of evidence, Barber et al. (2000) have identified 3 climate regimes in the period from the earliest 19th to the early 20th century and 2 regimes in the 20th century for the BNZ site and interior Alaska. The regimes affect radial growth, cone production, and seed crops for white spruce and the spatial extent of wildfire. These investigators found that the greatest magnitude of rapid decline in radial growth in the record characterize the latest climate regime that began in the 1970s. Analogous climatic regimes were found at and around the AND site, and these are believed to impact the catch of coho salmon off the coast of Oregon and Washington (Greenland 1996)

The above examples demonstrate the kinds of ecosystem responses that occur in relation to the types of climatic variability described in this paper. Continuing studies in the LTER program will undoubtedly reveal new insights into climate variability and ecosystem response.

\section{DISCUSSION AND CONCLUSIONS}

The above analyses have yielded important information in relation to temporal variability at LTER sites.

(1) We find that there are significant trends in the climate record of some but not all sites. Also it is common for the trends to appear in some seasons and not in others. The LTER sites with the longer proxy records show several statistically significant trends in temperature. Only JRN shows a long-term trend (increasing) in annual precipitation, although CWT, KNZ, LUQ (increasing) and SEV (decreasing) show long-term precipitation trends in individual seasons.

(2) A step function centered on 1976 was detectable in several of the LTER groups and in various seasons. The time series plots for Alaska and PNW sites suggest that important climatic changes have occurred there since the mid-1970s, possibly associated with the PDO.

(3) El Niño/Southern Oscillation (ENSO) signals in the temperature or precipitation were not thoroughly examined in this paper but have been treated in detail elsewhere (Greenland 1999). Greenland identified the LTER sites that display the strongest ENSO climatic signal (AND, LUQ, PAL). He also found that some sites (SEV and NTL) that had a weaker climatic signal could still manifest marked ecological effects related to the ENSO phenomenon. 
(4) Based on the grouping developed elsewhere, and the ways in which the climate of the sites varied when viewed with 5 yr moving averages, we found there was coherence among the climates of some groups of LTER sites but not of others. The greatest coherence was found for the North Central and East Coast groups, followed by the Alaska/PNW and the Antarctic sites. There was a fairly good correspondence in all of these groups between STAs, SPAs, and the values of the TIs such as NAO and PNA. This demonstrates that the climates of these sites are well integrated with the regional climates. On the other hand there was little coherence between the climates at individual sites of other regional groups. However, there were some interesting relationships found-particularly an inverse one between the SPAs at NWT and LUQ.

Our overall goal was to provide a characterization of climate variability at the LTER sites in terms of synoptic-scale factors producing variability within and between years. This was achieved for most of the groups of LTER sites identified by comparing their variability with that of teleconnective indices. Within the framework of the overall goal our sub-goals were achieved in firstly identifying the major changes and types of changes which have taken place at the LTER sites; secondly placing the climate variability at LTER sites in the context of what is already known at the national and global level; thirdly grouping LTER sites into categories of somewhat similar behavior as far as climate variability is concerned; and fourthly pointing out linkages and potential linkages between the climate variability and the ecosystem response.

This systematic investigation of the entire LTER Network, as it existed in 1996, has provided important insights into how the Network as a whole functions with respect to climatic variability. Investigators at individual sites are encouraged to use the above analyses as a jumping-off point for further analyses of their own. Those with expert knowledge of their own ecosystem will be able to tailor such analyses better to their own ecological needs. As increasingly longer period data are collected at the sites and as new proxy data and its better use become available, our knowledge and understanding of climatic variability and its effects on ecosystems will continue to improve.

Acknowledgements. This study was supported by the National Science Foundation (NSF) through Grant Number DEB 9416820 and through the University Corporation for Atmospheric Research's Climate System Modeling Program. The National Center for Atmospheric Research is sponsored by NSF. We wish to thank Ms Lynn Rosentrater, who collected the data and performed the analyses, Nathan Mantua and Michael Halpert, who directed us to the teleconnective index data, and 3 anonymous reviewers, who made many constructive comments.

\section{LITERATURE CITED}

Barber V, Juday GP, Finney BP (2000) Rapid change in climate and tree ring variables in boreal white spruce: a 200 year perspective from interior Alaska. Paper presented at the LTER All Scientists Meeting, Snowbird, Utah, August 3, 2000

Blair J, Shaver G (1999) Annual variation in terrestrial NPP. Paper presented at symposium on 'Patterns and Control of Net Primary Productivity Across Biomes', October 2, 1999. Hubbard Brook Experimental Forest, NH

Bolin B, Doos RR, Jager J, Warrick RA (eds) (1986) Greenhouse gases, climatic change, and ecosystems. Wiley, Chichester

Callahan JT (1984) Long-term ecological research. Bioscience 34(6):363-367

Cayan DR (1992) Latent and sensible heat flux anomalies over the northern oceans: driving the sea surface temperature. J Phys Oceanogr 22(8):859-881

Dahm CN, Molles MC Jr (1992) Streams in semi-arid regions as sensitive indicators of global change. In: Firth $\mathrm{P}$, Fisher S (eds) Troubled waters of the greenhouse earth. Springer-Verlag, New York, p 250-260

Dahm CN, Moore DI (1994) The El Niño/ Southern Oscillation phenomenon and the Sevilleta Long-Term Ecological Research site. In: Greenland D (ed) El Niño and LongTerm Ecological Research (LTER) sites. LTER Publication No. 18, LTER Network Office, University of Washington, College of Forest Resources, AR-10, Seattle, WA p 12-21

Dettinger MD, Ghil M, Kleppenne CL (1995) Interannual and interdecadal variability in United States surface-air temperatures, 1910-87. Clim Change 31:35-66

Ebbesmeyer CC, Cayan DR, McClain DR, Nichols FH, Peterson DH, Redmond KT (1991) 1976 step in the Pacific climate: forty environmental changes between 1968-1975 and 1977-1984. In: Betancourt JL, Tharp VL (eds) Proceedings of the Seventh Annual Pacific Climate (PACLIM) Workshop, April 1990. California Department of Water Resources, Interagency Ecological Studies Program, Technical Report 26, p 115-126

Epstein HE, Lauenroth WK, Burke IC (1997) Effects of temperature and soil texture on ANPP in the US. Great Plains Ecol 78:(8):2628-2631

Fraser WR, Trivelpiece WZ, Ainley DG, Trivelpiece SG (1992) Increases in Antarctic penguin populations: reduced competition with whales or a loss of sea ice due to environmental warming? Polar Biol 11:525-531

Greenland D (1989) The climate of Niwot Ridge, Front Range, Colorado, USA. Arctic Alpine Res 21(4):380-391

Greenland D (1995) Extreme precipitation during 1921 at the Niwot Ridge Long-Term Ecological Research Site, Front Range, Colorado, USA. Arctic Alpine Res 27(1):19-28

Greenland D (1996) Offshore Coho Salmon Populations near the Pacific Northwest and Large Scale Atmospheric Events. In: Isaacs CM, Tharp VL (eds) Proceedings of Twelfth Pacific Climate (PACLIM) Workshop, May 2-5, 1995. California Department of Water Resources. Interagency Ecological Studies Program, Technical Report 46, p 109-120

Greenland D (1999) ENSO-related phenomena at Long-Term Ecological Research sites. Phys Geogr 20(6):491-507

Hurrell JW, Van Loon H (1997) Decadal variations in climate associated with the North Atlantic Oscillation. Clim Change 36:301-326

IGBP (1990) International Geosphere-Biosphere Programme: a study of global change. The Initial Core Projects, Report no. 12. IGBP, Stockholm 
Karl TR, Williams CN Jr, Quinlan FT, Boden TA (1990) United States Historical Climatology Network (HCN) serial temperature and precipitation data. Environmental Science Division, Publication No. 3404, Carbon Dioxide Information and Analysis Center, Oak Ridge National Laboratory, Oak Ridge, TN

Karl TR, Knight RW, Easterling DR, Quayle RG (1996) Indices of climate change for the United States. Bull Am Meteorol Soc 77(2):279-292

King JC (1994) Recent climate variability in the vicinity of the Antarctic Peninsula. J Clim 14:357-661

Kittel TGF (1990) Climatic variability in the shortgrass steppe. In: Greenland DE, Swift LW Jr (eds) Climate variability and ecosystem response. US Forest Service, Southeastern Region Gen Tech Rep SE 65:67-75

Lauenroth WK (1999) Large scale net primary productivity patterns in grasslands. Paper presented at a symposium on 'Patterns and control of net primary productivity across biomes', October 2, 1999. Hubbard Brook Experimental Forest, NH

Linacre E (1992) Climate data and resources: a reference and guide. Routledge, New York

Mantua NJ, Hare SR, Zhang Y, Wallace JM, Francis RC (1996) A Pacific interdecadal climate oscillation with impacts on salmon production. Bull Am Meteorol Soc 78:1069-1079

Melillo JM, Callaghan TV, Woodward FI, Salati E, Sinha SK (1990) Effects on Ecosystems. In. Climate change: the IPCC scientific assessment. Cambridge University Press, Cambridge, p 283-310

Melillo JM, Prentice IC, Farquhar GD, Schulze E-D, Sala OE (1996) Terrestrial biotic responses to environmental change and feedbacks to climate. In: Houghton JT, Meira Filho LG, Callander BA, Harris N, Kattenberg A, Maskell K (eds) Climate change 1995: the science of climate change. Cambridge University Press, Cambridge, p 445-481

Molles MC Jr, Dahm CN (1990) A perspective on El Niño and El Niña: global implications for stream ecology. J N Am Benthol Soc 9:68-76

Nicholls N, Gruza GV, Jouzel J, Karl TR, Ogallo LA, Parker DE (1996) Observed climate variability and change, Chap 3. In: Houghton JT, Meira Filho LG, Callander BA, Harris N, Kattenberg A, Maskell K (eds) Climate change 1995: the science of climate change. Cambridge University Press, Cambridge, p 133-192

Ruddiman WF (2000) Earth's climate: past and future. WH

Editorial responsibility: Brent Yarnal,

University Park, Pennsylvania, USA
Freeman, New York

Skaggs RH, Baker DG (1989) Temperature change in Eastern Minnesota. J Clim 2:629-630

Smith RC, Stamerjohn SE, Baker KS (1996) Surface air temperature variations in the Western Antarctic Peninsula Region. In: Foundations for ecological research west of the Antarctic Peninsular. Antarctic Research Series, Vol 70. American Geophysical Union, Washington, DC, p 105-121

Stammerjohn SE, Smith RC (1997) Opposing ocean climate patterns as revealed by trends in regional sea ice coverage. Clim Change 37:617-639

Stark P (1994) Climatic warming in the central Antarctic Peninsula area. Weather 49:215-220

Swetman TW, Betancourt JL (1998) Mesoscale disturbaance and ecological response to decadal climate variability in the American Southwest. J Clim 11(12):3128-3147

Swift LW Jr, Waide JB, White DL (1990) Application of the Z-T extreme event analysis using Coweeta streamflow and precipitation data. In: Greenland DE, Swift LW (eds) 1990 Climate variability and ecosystem response. United States Forest Service, Southeastern Region, General Technical Report SE-65, p 13-18

Tilman D, Downing JA (1994) Biodiversity and stability in grasslands. Nature 367:363-365

Tilman D, El Haddi A (1992) Drought and biodiversity in Grasslands. Oecologica 89:257-264

Trenberth KE, Hurrell JW (1994) Decadal atmosphere-ocean variations in the Pacific. Clim Dyn 9:303-319

Van Cleve K, Martin S (1991) Long-Term Ecological Research in the United States: a network of research sites, 6th edn (revised). LTER Publication No. 11. Long-Term Ecological Research Network Office, Seattle, Washington

Van Loon H, Rogers JC (1978) The see-saw in winter temperatures between Greenland and northern Europe Part I: general description. Mon Weather Rev 106:296-310

Vaugnhan D, Lachlan-Cope T (1995) Recent retreat of ice shelves on the Antarctic Peninsula. Weather 50(11): 374-376

VEMAP Members (1995) Vegetation/Ecosystem Modeling and Analysis Project (VEMAP): comparing biogeography and biogeochemistry models in a continental-scale study of terrestrial ecosystem responses to climate change and $\mathrm{CO}_{2}$ doubling. Global Biogeochem Cycles 9:407-437

Wilks DS (1995) Statistical methods in the atmospheric sciences. Academic Press, San Diego

Submitted: April 20, 1999; Accepted: May 10, 2001 Proofs received from author(s): September 13, 2001 